\title{
Ethics of the Foucauldian Body
}

\author{
by \\ Zachary Fouchard
}

\begin{abstract}
A thesis submitted to the Faculty of Graduate and Postdoctoral Affairs in partial fulfillment of the requirements for the degree of

Master of Arts

in

Philosophy
\end{abstract}

Carleton University

Ottawa, Ontario

○ 2013 Zachary Fouchard 
Library and Archives

Canada

Published Heritage

Branch

395 Wellington Street

Ottawa ON K1A ON4

Canada
Bibliothèque et

Archives Canada

Direction du

Patrimoine de l'édition

395 , rue Wellington

Ottawa ON K1A ON4

Canada
Your file Votre référence

ISBN: 978-0-494-94607-7

Our file Notre référence

ISBN: $978-0-494-94607-7$
NOTICE:

The author has granted a nonexclusive license allowing Library and Archives Canada to reproduce, publish, archive, preserve, conserve, communicate to the public by telecommunication or on the Internet, loan, distrbute and sell theses worldwide, for commercial or noncommercial purposes, in microform, paper, electronic and/or any other formats.

The author retains copyright ownership and moral rights in this thesis. Neither the thesis nor substantial extracts from it may be printed or otherwise reproduced without the author's permission.
AVIS:

L'auteur a accordé une licence non exclusive permettant à la Bibliothèque et Archives Canada de reproduire, publier, archiver, sauvegarder, conserver, transmettre au public par télécommunication ou par l'Internet, prêter, distribuer et vendre des thèses partout dans le monde, à des fins commerciales ou autres, sur support microforme, papier, électronique et/ou autres formats.

L'auteur conserve la propriété du droit d'auteur et des droits moraux qui protege cette thèse. $\mathrm{Ni}$ la thèse ni des extraits substantiels de celle-ci ne doivent être imprimés ou autrement reproduits sans son autorisation.
In compliance with the Canadian Privacy Act some supporting forms may have been removed from this thesis.

While these forms may be included in the document page count, their removal does not represent any loss of content from the thesis.
Conformément à la loi canadienne sur la protection de la vie privée, quelques formulaires secondaires ont été enlevés de cette thèse.

Bien que ces formulaires aient inclus dans la pagination, il n'y aura aucun contenu manquant. 


\section{Abstract}

This study has two major purposes: (1) to deliver an exegetical reading of Michel Foucault's History of Sexuality, Volume 1: The Will to Knowledge (1978); and (2) to extrapolate from within this text an ethics of the Foucauldian body. The study will at once describe the mechanisms of power which Foucault believes place "sex" within the body as something other than sensual pleasure, and draw out the movement of Foucault's thought as it balances between its overall descriptive and prescriptive ethical claims. In conclusion, it will be shown that while Foucault presents a descriptive ethics of the historical and political construction of sex and the body, a prescriptive ethics of the body figures within The Will to Knowledge that calls for a transformation of the present hold power has on the body based on the polymorphous character of power and the heterogeneous character of the body. 


\section{Acknowledgements}

The following would not have been possible without the constant support of three

important women: Dr. Geraldine Finn, my thesis supervisor; Chantal St-Denis, my loving mother; and Darlene Drecun, my colleague and partner. 


\section{Table of Contents}

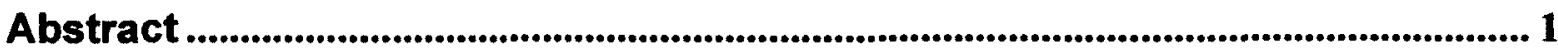

Acknowledgements .......................................................................................................................... 2

Table of Contents................................................................................................................................ 3

Introduction ................................................................................................................................. 4

1 Chapter: Foucault's History of Sexuality ...................................................................... 9

1.1 Form and Content .................................................................................................

1.2 We "Other Victorians" ............................................................................................ 13

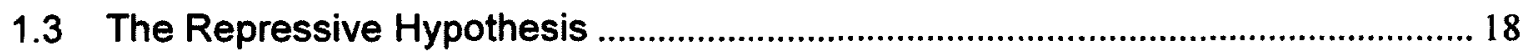

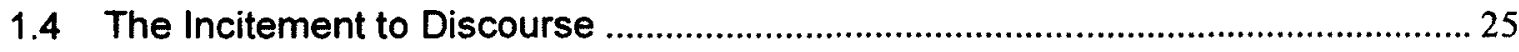

2 Chapter: Of Other Sexualities ....................................................................................... 34

2.1 The Multiplication of Polymorphous Powers.......................................................... 34

2.2 Productive Power ..................................................................................................... 39

2.3 The Perverse Implantation ....................................................................................... 44

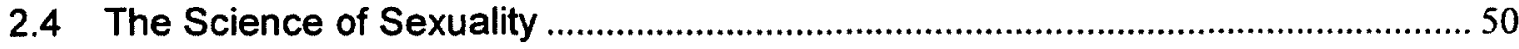

3 Chapter: The Ethics of the Foucauldian Body ….............................................5 57

3.1 The Will to Know Sex ......................................................................................... 57

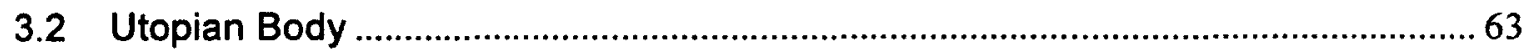

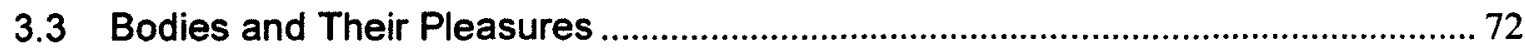

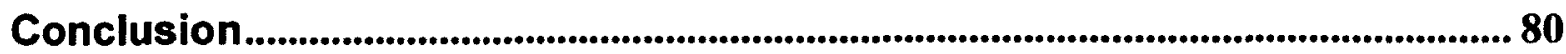

Bibliography ....................................................................................................................................... 82 


\section{Introduction}

French philosopher Michel Foucault is best known for his work on the philosophy of power. His various critical studies of social institutions, most notably psychiatry, medicine, the prison system, and the history of human sexuality, constitute an invaluable resource for understanding the various ways in which power can be exercised and used as a form of social control. The originality of Foucault's work was a matter of his ability to describe power not as unidirectional and exercised by single individuals or unitary oppressive systems, but rather as blind and multidirectional operations exercised through institutions that only appear to be neutral or benevolent. In this way, Foucault was better able to account for the more insidious functions of power according to which power can be exercised not only from above but also from below, and not only from without but also from within.

The objectives of Foucault's critical studies can be summarized as various critiques of the norms and mechanisms of power according to which individual and collective identities are made to exercise powers unto and from within themselves. In this sense, Foucault's work is a matter of underlining the extent to which the definition of certain categories of identity and their ensuing social and political relationships are thoroughly invested with various forms of power. For example, Foucault famously claims in the first volume of The History of Sexuality (1978) that homosexual identity is a historical construct of the nineteenth century according to which previously existing moral and legal norms concerning sodomy shifted into principles of intelligibility and classification that were then accepted as 
natural and unmediated ways of understanding one's body and one's sense of self (see $1978,38,43,101)$. Thus, with special attention paid to the particular manner in which bodies are invested with mechanisms of power, Foucault is able to describe the very form which power adopts when it takes hold of, mediates between, and produces identities and categorical types of individuals.

As contemporary Foucault scholar Mathieu Potte-Bonneville has pointed out, Foucault's legacy can also be described as "an eruption of bodies" (2012, 22). The importance Potte-Bonneville places on the body as it figures throughout Foucault's work is noteworthy because, as it will be argued for here, the body is a principal site for both the application and the activation of power. Understanding how power is both applied to and activated within bodies, however, will require paying close attention to how the narrative form of a text like Foucault's History of Sexuality, Volume 1 echoes his description of the forms according to which power can be exercised. For the narrative forms of Foucault's texts express what, at the level of power, sustains the performance achieved in their reading.

For example, what Potte-Bonneville means by Foucault's legacy resulting in an "eruption of bodies" can be read straightforwardly as a sudden proliferation of the number of Foucauldian publications on the topic of the body. However, this "eruption of bodies" can also be read according to the literary form of the phrase, as an allusion to the violent emergences bodies can have in relation to power, and as a metaphorical description of these as explosive sensations of sexual pleasure and, more specifically, eruptions of male sexual discharge. Thus, by describing Foucault's legacy as "an eruption of bodies," Potte-Bonneville alludes 
to the lasting effect Foucault's work has had on contemporary scholarship, but also to the various material and sexual functions the body plays within his work, which support the importance of Foucault's legacy. As we shall see, the narrative form of the first volume of The History of Sexuality is made up of similar allusions that explicitly disrupt commonly-held views regarding power, sex, and the body, and actively demonstrates how power can take hold of the body in new and alternative ways.

Though the philosophical relationship between the narrative form of a text and the performance achieved in its reading cannot fully be explicated here, the issue can nonetheless begin to be unpacked insofar as it relates to the exploration of the details of Foucault's work. It will therefore be shown that the narrative forms of Foucault's texts constitute an important element supporting the movement and direction of his thought and the lasting legacy of his original claims and ideas. What follows, then, is a concise reader's guide to The History of Sexuality, Volume 1: The Will to Knowledge (1978) that identifies the text's main claims and provides a descriptive account of the philosophical operations that sustain them. [The movement of Foucault's thought will be shown to constitute a balance between descriptions of historical facts, on the one hand, and uses of literary devices, metaphorical images and multivalent terms (the word "eruption," for example, as commented upon by Potte-Bonneville) on the other hand. This two-way movement of Foucault's thought is, I suggest, the ground upon which the performance of this text is accomplished: providing a descriptive account of ethical issues regarding sexuality and the body, while at 
the same time enacting a prescriptive ethics of the body that actively reorients the Modern relationship between power and sex.

The first chapter will set the stage for reading the narrative form of Foucault's text on sexuality and will provide a detailed account of Foucault's claim that power produces sex rather than represses it. The second chapter will then examine how Foucault understands productive power and demonstrate how according to Foucault, power places "sex" within the body as something other than sensual pleasure. Finally, the third chapter will address the performance achieved in reading Foucault's text insofar as it provides a descriptive ethics of the history of sexuality, which results in a prescriptive ethics of the body that actively juxtaposes sex with pleasure.

Finally, it will be shown how Foucault's claim that certain categories of identity, such as that of the homosexual, are produced by power and internalized within bodies is a descriptive ethical claim. Foucault describes the process whereby certain individuals are made to necessarily recognize themselves as homosexual, for instance, and others as heterosexual. However, it will also be shown that where these identities may either be renewed or transformed into other forms of identity, there issues a stronger normative claim. Here, it will be demonstrated how Foucault prescribes that we seek out the transformation of current sexual identities from directly within the mechanisms of power that identify sex within the body. It will be shown, finally, that while Foucault presents a descriptive ethics of the historical and political construction of sex and the body, a prescriptive ethics of the body figures within The Will to Knowledge: an 
ethics that, near the end of the book, calls for a transformation of the present hold power has on the body from within the heterogeneity of the body and its pleasures - driven, ultimately, by the polymorphous character of productive power. 


\section{Chapter: Foucault's History of Sexuality}

\subsection{Form and Performance}

Foucault's language throughout The History of Sexuality, Volume I: The Will to Knowledge ${ }^{1}$ is dense and multilayered (1978). The complexity of each sentence is carefully crafted, relying heavily on literary devices such as allegory, satire and irony. The results produce various and often times unexpected experiences for the reader, from a page-turning sense of anticipation more frequently associated with reading fiction, to a jarring sense of confusion that can lead to the feeling of having a rug lifted from underneath one's feet. Foucault's demanding literary style is no less rewarding, however, as each turn of the page builds upon coherent lines of argumentation that, when read carefully, culminate in a great number of thought-provoking ideas.

The opening two sentences of the work are prime examples of Foucault's intricately rich use of literary prose.

For a long time, the story goes, we supported a Victorian regime, and we continue to be dominated by it even today. Thus the image of the imperial prude is emblazoned on our restrained, mute, and hypocritical sexuality. $(1978,3)$

The "story," as Foucault calls it, is as familiar to readers today as it was to the author's contemporaries in the late 1970 s. Sexuality has been thoroughly repressed ever since the prudery of the Victorian era overtook the Renaissance's open attitudes towards sex. Yet, Foucault's tentative language comes as a

\footnotetext{
' Histoire de la sexualité 1 : La volonté de savoir was first translated into English in 1978 under the title The History of Sexuality, Volume 1 : An Introduction. Penguin Books finally adopted the more exact subtitle in its 1998 reprint of the text.
} 
surprise to any reader expecting the straightforward narrative of a traditional historical account. The open-ended idiom, "for a long time," can easily be read in the same way one reads the "once upon a time" beginnings of fairy tales and other works of fiction. The effect displaces any reader's expectations of a simple recitation of established historical facts; but it remains unclear whether Foucault will portray sexuality's repression by the Victorian bourgeoisie as an erroneous account we have been made to believe is true. The reader must decipher Foucault's position with careful attention paid to the text's narrative form and its literary devices.

For example, the introductory lines quoted above echo the first sentence of Marcel Proust's masterful novel, In Search of Lost Time ${ }^{2}$ (Proust 1922/2005; see Beer 2002,10 ). Proust's famous autobiographical novel addresses the themes of time and memory by juxtaposing the narrative points of view of a narrator who is continually falling in and out of sleep ${ }^{3}$ (see Foucault 2006, 234n2). Similarly, Foucault's Will to Knowledge addresses the historical status of sexuality's repression by the Victorian bourgeoisie from different narrative points of view, assenting, dissenting and adopting various other positions that touch the collective memories of the reader's present circumstances.

As the story goes, an immodest frankness regarding sex was still very common near the end of the Renaissance, in the seventeenth century (Foucault

\footnotetext{
2 "For a long time I used to go to bed early." (Proust 1922/2005, 1)

3 "When a man is asleep, he has in a circle round him the chain of the hours, the sequence of the years, the order of the heavenly host. Instinctively, when he awakes, he looks to these, and in an instant reads off his own position on the earth's surface and the amount of time that has elapsed during his slumbers; but this ordered procession is apt to grow confused, and to break its ranks." (Proust 1922/2005, 5-6)
} 
1978, 3). It remained a period in which "bodies made a display of themselves" (ibid.) by ostensibly "strutting their stuff" out in the streets. We also seem to remember the Renaissance as a time where codes of conduct regulating one's familiarity with the illicit were much more lax than those of the nineteenth century (ibid.). The Victorian era of the end of the nineteenth century, we say, confined the display of bodies to the bedroom of the conjugal family. It was a time when bodies avoided contact with each other; when the procreative couple took custody of a carefully confined sexuality and all that did not contribute to the norms of utility and fertility were deemed intrinsically tainted by abnormality (ibid. 3-4). Sexuality was not prohibited, we say, but was rather characteristically repressed (ibid. 4). The visible, the sterile and the abnormal were deemed taboo and were reduced to silence and nonexistence (ibid. 4-5).

This version of the history of sexuality is an almost exact reiteration of the views of Wilhelm Reich, whose 1936 book The Sexual Revolution had regained a widespread prominence in the 1960 s and 1970 s (Eribon 2001, 43). Reich's story of sexuality's repression and the rise of modern puritanism is thus the object of ironic reference when Foucault states that today's sexuality is emblazoned with the image of the imperial prude (see 1978, 3). According to Foucault, it is Reich, primarily, who is responsible for the widespread view that sexuality has been historically repressed - a view that Foucault saw as one of the main calls to arms of the sexual liberation movement of his time. For Foucault, Reich's portrayal of modern sexuality as restrained, mute and hypocritical was being upheld as the main features of sexuality from the Victorian era up until the 1970s, which 
necessarily led to the view that sexuality needed to be liberated from its supposed historical and political repression. Foucault's ironic tone, however, indicates that he is skeptical of this historical assessment and the corresponding view that liberation from repression will once again allow for the unfettered expression of sex.

One can read in the opening lines of The Will to Knowledge a recitation of the Reichian argument that, if the image of the imperial prude is emblazoned on modern sexuality's coat of arms, then the image of a sexuality liberated from repression will be emblazoned upon the heraldry of tomorrow's sexual revolution. Foucault's militaristic language is a historically and politically potent literary device (see Beer 2002, 11). For example, coats of arms are often lauded as "the shorthand of history" (Fox-Davies 1909/2007, v). On this point, Foucault's metaphor very subtly charges Reich with displaying a limited understanding of history. The blazon of a coat of arms also refers to the chambers of rhetoric of the fifteenth and sixteenth centuries, guilds of amateur playwrights, lyricists and actors that were highly influential in France and Holland throughout the Renaissance. While the rhetoricians of these emblazoned literary societies played an important role in promoting the ideas of religious and cultural reform that would lead to the sixteenth century Protestant Reformation, they did not shy away from presenting these reforms in ways that best supported their influence in society (see Waite 2000). Thus, the reference to coats of arms and emblazoned images suggests that Reich's understanding of sexuality as historically repressed may itself be a politically repressive view of sex. 
The use of militaristic language makes it clear that an assessment of the history of sexuality will indeed require a particular attention paid to the notion of power and its relationship to sex. However, Foucault's use of the image of coats or arms further suggests that Foucault will pay special attention to the form which power takes, assessing whether it is repression which has been emblazoned upon sexuality, or whether in actual fact sexuality wears a different coat of arms altogether.

\subsection{We "Other Victorians"}

According to the point of view that Foucault attributes to Reich, the faltering logic of Victorian sexuality - restrained, mute and hypocritical represses the expression of sex according to a "triple edict of taboo, nonexistence, and silence" (Foucault 1978, 5). Here, sex is hypocritically prohibited, denied and censured in all its forms of expression. However, as the story goes, sex could never be completely eradicated; and so, if Victorian society had to somehow make room for those sexualities which made themselves too visible, did not conform to procreative modes of existence, or were just plain abnormal, it was reasoned that they should be confined to places reserved for them at the very limits of society. "[L]et them take their infernal mischief elsewhere," it was reasoned, to places where "they could be reintegrated, if not in the circuits of production, at least in those of profit" (ibid. 4). The brothel and the mental hospital would become these supposed places of tolerance, where the prostitute, the client and the pimp, as well as the psychiatrists and his hysteric, 
could be somewhat integrated into Victorian society (ibid.). These "other Victorians," as Steven Marcus called them in his 1966 study of the underbelly of Victorian sexual culture, spoke of silenced pleasures and engaged in unnamed acts of sexual indulgence (see Marcus 2008). However, wild and untrammelled sex was carefully insulated by "clandestine, circumscribed and coded types of discourse" (Foucault 1978, 4), and would remain so until the social movements responsible for the sexual revolution of the 1960 s and 1970 s liberated us from the sexually repressive regimes of the Victorian bourgeoisie.

However, another point of view - Foucault's, this time - is skeptical about the extent to which we have liberated ourselves from this two-century-old story of increasing repression $(1978,5)$. "[C]ould things have been otherwise?" (ibid.), asks Foucault. Is indeed repression the fundamental means by which sex has been allowed to speak, whether from the bedroom or the brothel, since the end of the Renaissance? If this were the case, hypothesizes Foucault, then nothing less than a complete overturning of society - "a transgression of laws, a lifting of prohibitions, an eruption of speech" (ibid.) - would free us from the repressive powers castigating our prudish sexuality. According to the logic of the "repressive hypothesis," only a mechanism of power entirely different from that of repression could allow for such an unfettered expression of sex. In turn, this new power of free expression would have a lasting effect on all other social and political realms - for, as Foucault quips, "the least glimmer of truth is conditioned by politics" (ibid.). 
Here, Foucault's skeptical, dissenting voice is carefully buried between other narrative voices that can be traced back to the theoretical work of Wilhelm Reich, the commonly-held opinions of yesterday's sexual revolutionaries, and even today's gender-bending freedom fighters. For Foucault, the question of whether we have, today, inherited a sexuality that is fundamentally repressed is not a matter of theoretical discourse or even of medical practice, but rather requires an inquiry into the forces of power and politics at work when sexuality takes hold of the body $(1978,5)$. Thus, Foucault denounces the work of Reich, who he charges with displaying an obvious timidity behind the vehemence of his speech (ibid.). Foucault is even suspicious of the work of Sigmund Freud, despite his having dreamed up an entirely novel description of the relationship between sex and power. According to Foucault, if sexuality was truly repressed in the Victorian era, indeed some progress may have been made when Freud offered the Western world a fresh perspective on the notions of sex, desire, and sexual fantasy. However, Freud also consistently upheld the norms of medical prudence attempting to guarantee the innocuousness of the scientist's power of observation, which for Foucault only ensured that sex did not over-saturate the "safe space" between the doctor's couch and the patient's whispers (ibid.).

According to Foucault, the solemn discourse upholding sexuality's continued repression is reinforced by the ideas of Reich, and even Freud. It is for this reason that Foucault takes up the question of sexuality as it figured at the centre of the "sexual revolution" of the 1960 s and 1970s, claiming that repression 
was being upheld as sexuality's fundamental characteristic only because of the historical and political guarantees protecting such a view $(1978,5)$.

First, placing the birth of sexuality's repression at the end of the Renaissance allows for a view of the history of sexuality as coinciding directly with the development of capitalism and the ceremonious establishment of the modern bourgeoisie late in the seventeenth century $(1978,5)$. Such a view of history, says Foucault, is simply too easy to uphold - it turns sex into a catalyst for the historical development of capitalism and the imperatives of labour and production, when the recent history of sexual identity and the politics of nonreproductive pleasures could well have emerged more independently and for reasons altogether different from those associated with the social transformations caused by the Industrial Revolution (ibid. 5-6). It is almost as if it were deemed necessary to claim that visible, sterile and abnormal pleasures were made to be taboo and were reduced to silence and nonexistence in ways that were directly correlated with the early advances of capitalism, if sex were to ever be taken on as a political cause and if its liberation were to be sought in the name of tomorrow's revolution (ibid. 6).

Thus, in a second place, it may also be to the speaker's benefit to equate the relationship between sex and power with repression; for if sex is repressed, then the mere mention of it gives the speaker an air of radical, transgressive defiance $(1978,6-7)$. Placing sex "on the agenda for the future," by attempting to liberate sexuality from its historical repression, gives the sexual revolutionary the appearance of speaking from outside of the power of repression, as if somehow 
independent of power and repression (ibid.). "Tomorrow," we affirm, "sex will be good again" $(1978,7)$ and we will finally be able to bring together those most disparate eschatological themes, "revolution and happiness," "revolution and pleasure," or "revolution and a different body, one that is newer and more beautiful" (ibid.).

However, when this supposedly revolutionary discourse speaks out against the established order, when enlightenment, liberation and pleasure are united in an attempt to reveal the truest nature of human sexuality, those "other Victorians" said to be the most repressed ironically begin to fade away in favour of sexualities that are no longer transgressive $(1978,5$; see 1978,7$)$. Says Foucault (straightforwardly, this time), what stands out from a retelling of the story of sexuality's repression, in connection with the historical advantages of its supposedly revolutionary promises and the political gains of its recitation, is that the affirmation of sexuality's repression is consistently coupled with a grandiloquent discourse attempting to reveal the truth about sex and the promise of a better future $(1978,8)$. The "statement of oppression" and the "form of the sermon" mutually reinforce one another, in that speaking of repression is necessarily spoken with a lyricism and religiosity that has long accompanied revolutionary projects of the past (ibid. $7-8$ ). How is it, then, that the verbosity of modern discourse on sex plays a prophetic function similar to the discourses animating the Crusades or the Inquisition? And, conversely, if a "great sexual sermon" is a major highlight of the past few decades, will we not, then, soon 
arrive at sexuality's "promised land," where the other pleasures of the Victorian underground are freed from the shackles of abnormality?

\subsection{The Repressive Hypothesis}

In providing alternative points of view regarding the inheritance of a prudishly repressed sexuality, Foucault sets out to examine how talk of sexuality is necessarily accompanied by social criticism. Western society, says Foucault, "has been loudly castigating itself for its hypocrisy for more than a century," has spoken at lengths of its silence on the topic of sex, and relates in great detail those sexualities which are said to have no place in the social sphere $(1978,8)$. How ironic, notes Foucault, that sexuality is upheld as essentially repressed, when this same repressive society has gone to great lengths in order to continually speak about the repression, prohibition, censorship and denial of sex.

It is for this reason that Foucault raises a number of doubts concerning sexuality's repression during the Victorian era. He questions whether repression most properly characterizes the relationship between sex and power since the Renaissance and his inquiry begins by addressing this "repressive hypothesis" $(1978,10)$. However, rather than directly asking the question of whether sex has been historically repressed, Foucault orients his inquiry towards the reasons why we say, with so much passion and resentment, that our sexuality is repressed (ibid. 8-9). As he explains, such an orientation allows Foucault to address historical discourses concerning sex, whether repressed or otherwise, from a 
perspective that aims to draw out the initial impetus to speak of sex and the forces sustaining it (ibid.).

"Is sexual repression truly an established historical fact?" $(1978,10)$ First, Foucault wonders whether repression constitutes the fundamental characterization of sexuality since the Renaissance and whether, as a matter of legitimate hypothesis, our modern sexuality is just as historically repressed (ibid.). "Do the workings of power [...] really belong primarily to the category of repression" (ibid.). Second, Foucault wonders whether it is in fact repression which truly constitutes the fundamental mode of expression of power and whether, as a matter of sexuality's hypothesized repression, the notions of prohibition, censorship and denial constitute the theoretical, as well as historical, characterization of the relationship between power and sex in the modern era (ibid.). "Was there really a historical rupture between the age of repression and the critical analysis of repression?" (ibid.) Third, Foucault wonders whether the sexual liberation movement's criticism of sexual repression has, in actual fact, effectively countered mechanisms of power that have gone unchallenged for over two centuries (ibid.). He also begins to formulate his own hypothesis regarding the recent history of sexuality and the political formulations of its current criticism, hinting that it may be the case that "sexual liberation" belongs to the same mechanisms of power as that which hypothesizes sexuality to be historically repressed and power to be theoretically repressive (ibid.).

Foucault's reasons for doubting the repressive hypothesis, he clarifies, are not aimed at either denying that sexuality was ever repressed or affirming that 
the sexual liberation movement has been unsuccessful in promoting greater liberties concerning the expression of sexual identities (1978, 10-11). Rather, his aim is to develop an inquiry into the "repressive hypothesis" from the point of view of what he calls the "discursive economy of sex" (ibid. 11). He asks,

"Why has sexuality been so widely discussed, and what has been said about it? What were the effects of power generated by what was said? What are the links between these discourses, these effects of power, and the pleasures that were invested by them? What knowledge (savoir) was formed as a result of this linkage?" $(1978,11)$

The object is not to determine whether one says yes or no to sex, whether sex is expressed as a matter of permission or prohibition, but rather to account for the very fact that sex is spoken about in the first place $(1978,11)$. The term "discursive economy" alludes to the notion of political economy, or what today is simply known as economics; that is, the study of the conditions under which polities or states produce and distribute their resources and wealth, in relation to laws, customs and other political processes. Thus, Foucault suggests that the question of sexuality's repression and its future liberation is most aptly handled from a point of view that addresses the conditions under which sex has been "put into discourse," as well as the relation such conditioning factors share with the political processes of law and morality.

Says Foucault, sexuality is to be addressed from the point of view of the "regime of power-knowledge-pleasure" sustaining discourse on sex throughout the Modern period (ibid.). Referring to a regime or set of political conditions, Foucault seeks to determine whether or not sexuality has been historically repressed by outlining sexuality's historical and political conditions of emergence. In Foucault's words, the aim is to determine how power has influenced the 
modern history of sex by determining who has been speaking about it; how knowledge has been used to identify the narrative voices and epistemic perspectives from which this speech has occurred; and how pleasure has been factored into the pursuit of sexual activities, interests and identities by clarifying which institutions prompt people to speak about sex and how these institutions distribute and store what is said about it (see 1978, 11).

The notion of power is of utmost importance because, following the model of political economy, it is power which conditions how sex discourses are produced and distributed, whether it functions according a model of law, morality, or any other. Knowledge is also a notion that must be addressed, because it is knowledge, in connection with power, which determines the contents of sex discourses and identifies who is allowed to speak of sex and who is not. Finally, pleasure, too, is very important to Foucault's inquiry because it is a focus on pleasure, in connection with knowledge and power, that will determine what is allowed to be expressed in and by sex, and what it is not, as well how individual relationships and collective institutions will condition sexual expression. Again, in Foucault's words, the approach is based on extracting from discussions of sexuality "the will that sustains them and the strategic intention that supports them" $(1978,8)$, by determining the way in which power, knowledge and pleasure have been united under a single apparatus for speaking about sex.

Foucault thus counters the "repressive hypothesis" with a hypothesis of his own: social criticisms of sexuality rooted in the discourses of the 1960s and 1970 s denounce the very powers that sustain its discourse on sex; they promise 
to liberate sex from the very prohibitions that keep us talking about it $(1978,8)$. Such a reversal of perspective is made possible by what Foucault calls the overall "discursive fact" regarding sex: the historically situated way in which sex has been "put into discourse" (ibid. 11). The reversal is also made possible by what Foucault has called the discursive economy of sex: the historically situated ways in which sex has been given a certain value and has been allowed or prohibited to speak from a privileged or underprivileged voice.

Foucault's hypothesis on sexual repression and liberation addresses the form according to which power has "put sex into discourse" and has channelled sex according to regulatory codes that either allow or disallow it to speak or be spoken about $(1978,11)$. This, Foucault argues, will provide an alternative view on the issue of sexuality and repression by highlighting what he calls the "will to knowledge" that simultaneously supports the discursive fact regarding sex and acts as the sole instrument of its discursive economy (ibid. 11-12).

By addressing the relationship shared between sex and power rather than theoretical discourses and medical practices concerning sex, Foucault is able to question sexuality's repression at the very level of repression's functionality. Concentrating on the historical forms according to which power has influenced sex will, in this way, demonstrate whether or not sexuality has been prohibited, censured and outright denied. Foucault suspects that, as a matter of historical inquiry, it is rather the opposite that has occurred. This comes as a surprise to the reader because, as Foucault concedes, it is most often believed that power is primarily repressive - particularly in modern society, where fruitless energies, 
overly-intense pleasures and irregular behaviours are known to be carefully repressed $(1978,9)$. However, Foucault purports that there are reasons for the widespread acceptance of this stance - historical protections and political advantages - that, with a healthy dose of skepticism, can be countered in favour of an alternative view.

There is thus an important ethical component to Foucault's investigation into the history of sexuality's repression and attempted liberation. When power and knowledge act upon and influence the individual at the level of everyday pleasures, the effect is, at times, that of repression, prohibition and censorship, but also "incitement and intensification" (ibid.). Thus, in a first place, the relationship established between sex and power is one in which power takes hold of the body. On this point, Foucault will demonstrate that writing the history of sexuality is a matter of retracing the historical transformations according to which sex is incited and ultimately produced within the body. However, by demonstrating that this same relationship between sex and power takes place from within a materiality of the body that is subject to historical transformations, Foucault is at the same time opening his investigation to the possibility of further transformations of the body. Thus, in a second place, mapping the history of sexuality necessarily involves a critical, normative ethics of the body insofar as Foucault's inquiry involves a loosening of the grip of power upon the body in relation to sex and its everyday pleasures.

Thus, where the "repressive hypothesis" unites the well-known negative functionalities of power under a single flag, rallying power, knowledge and 
pleasure together to form "one great central mechanism destined to say no," Foucault proposes a counter hypothesis according to which repression is but a component of a much larger historical framework $(1978,12)$. Foucault proposes that sexuality's repression has acted as somewhat of a distraction from a more general transformation of sex into discourse and a will to knowledge whose historical mechanisms and techniques of power cannot be reduced to a negative characterization of power (ibid.). Foucault's inquiry disengages the history of sexuality from what he calls principles of scarcity and rarity, demonstrating that sex's general economy rather functions according to "instances of discursive production," incurring "the production of power" and "the propagation of knowledge" (ibid.). Foucault's first volume of The History of Sexuality, then, is a historical survey of these instances of production and their transformations, where the discursive production of sex primarily functions in an inciting rather than restricting manner (ibid. 12-13). As Foucault demonstrates, the mechanisms of this increasing incitement were accompanied by a novel set of technologies of power that followed what Foucault calls a principle of dissemination and implantation of "polymorphous sexualities" (see ibid.). Thus, concludes Foucault, the will to know sex has not halted in confrontation with a set of taboos that must be lifted, but has instead acted as the main proponent for the establishment of a veritable science of sexuality (ibid. 12-13). The story of sexuality's repression, then, is but a chapter in a larger chronicle of historical transformations occurring between powers, sets of knowledge, and pleasures, which Foucault will recast in light of very production of a novel category of identity called "sexuality." 


\subsection{The Incitement to Discourse}

Over the course of the past three centuries, transformations occurring at the level of discourses surrounding sex have resulted in what Foucault calls "a veritable discursive explosion" $(1978,17)$. This is not to say that there wasn't a policing of statements controlling who can speak of sex and when and where sex could be spoken of (ibid. 17-18). However, Foucault points out that, rather than simply constituting a restrictive economy, the policing of statements also resulted in a multiplication of discourses concerning sex (ibid. 18). Foucault describes this multiplication according to the expansion of the fields of discourse within which power could be exercised over and through sex (ibid.). At the outset of the seventeenth century, following the great social redistributions of the French grand siècle and the Enlightenment period, areas were established where talk of sex was restricted to norms of tact and discretion, if not complete silence (ibid.). New restrictive norms were incorporated into the politics governing language and speech (ibid.). At the same time, however, there grew out of the seventeenth century discursive economy of sex an "institutional incitement" to speak about sex at greater lengths and to relate it in greater amounts (ibid.). More and more, individual relationships between parents and children, teachers and pupils, or masters and domestic servants, for example, were required by social and political institutions - the family, schools and households - to speak of sex and have sex spoken about, forcing such individuals to speak with "explicit 
articulation" and "endlessly accumulated detail," despite the restrictive economy governing language at the time (ibid.).

As an example of this incitement to discourse, Foucault outlines the case of the historical changes that took place within the Catholic Church during the Counter-Reformation, following the Council of Trent $(1978,18-20)$. In the middle of the sixteenth century, a great number of reform decrees were issued on a wide range of official Church teachings. Foucault explains that throughout the Middle Ages and up until as late as the seventeenth century the Catholic sacrament of penance was ordered in a way that purposefully avoided entering into any descriptive details of one's confessions (ibid. 18-19). Foucault cites the influential Italian orator Paolo Segneri (1695) and the canonized Italian bishop Alphonsus Maria de Liguori (1854) who were both still prescribing that confession and spiritual guidance heed a healthy distance from the precise description of sexual acts - assumed positions, for example, or the exact moments of pleasure (Foucault 1978, 18-19). However, as the influence of the Council of Trent began to be felt, the new Catholic pastoral began to more strongly prescribe what the likes of Michelangelo Tamburini, head of the Jesuits at the turn of the sixteenth century, and Thomas Sanchez, a Spanish Jesuit of similar penitentiary zeal, had been preaching all along: a greater importance in the sacrament of penance regarding an uncovering of the "insinuations of the flesh" (Foucault 1978, 19). Spiritual guidance still had to be wary of sex and its contaminating effects on one's purity of body and mind, but, henceforth, all the aspects and effects of sex were to be duly confessed with the utmost urgency (ibid.). Sinful flesh was well 
on its way to becoming the root of all evil and, concomitantly, there began a shift towards identifying the exact moment of sinful transgression; a shift that moved away from the act itself, towards the intricate "stirrings of desire" (ibid. 19-20). In sum, following the Council of Trent, Catholic spiritual guidance assumed carefully coded rules for discreetly putting sex into discourse; but, at the same time, sex was enveloped by a discourse that tracked it down to the most intimate twitching of the nerves of the flesh (ibid. 20).

Foucault thus hypothesizes that it was in the seventeenth century that the familiar injunction to speak the truth of sex with peculiar necessity took on the form, for the very first time, of a general constraint $(1978,20)$. Aside from the obligation to confess to violations of the laws of sex, there emerged, as a matter of traditional penance, a "nearly infinite task" of telling everyone everything that could possibility be imagined concerning sex; everything that concerned the "interplay of innumerable pleasures, sensations, and thoughts" (ibid.). Putting sex into discourse had long defined the Christian pastoral, but the seventeenth century devised a new rule that applied to all good Christians: You must seek to "transform your desire, your every desire, into discourse" (ibid.). In this way, the injunction, so familiar today, to speak of sex in the most intimate of details first appeared between the sixteenth and seventeenth centuries as what Foucault describes as a "constant optimization" and an "increasing valorization" of sex's new and unique discursive function (ibid. 23). What was noteworthy was the ability of discourse, when addressing sex, to displace, intensify, reorient and 
modify desire; but even more important was the necessity with which discourse was required to pursue increasingly intensified desires (ibid.).

Where the history of sexuality has so often been a matter of reconstructing the censorship of sex, Foucault works to relate the installation of an apparatus whose imperative is to produce increased quantities of discourses on sex at the same time as it functions within the general discursive economy of sex itself $(1978,23)$. This apparatus for the production of discourses on sex had the very particular effect of making talk of sex both a necessity and an imperative. The "putting into discourse" of sex became a matter of stimulating its own discursive economy and, at the site of Christian spirituality, something novel emerged: not so much a benign curiosity or sensibility, nor even a new mentality, but an entirely new network of power mechanisms (ibid.). It was sex, seen from an entirely new point of view - not because a new discovery had been made or because a new understanding had been aroused, but because the particular mechanisms inciting sexual discourse had changed. Talk of sex became a matter of increased quantity, but no sooner did it also become a matter of optimized quality.

It began at the site of the Christian pastoral, where confessors and spiritual directors increasingly touched the twitching nerves of the flesh, stirring the desires of the flock. The more straightforward investigations of Catholic penance then grew in scope and application, regularly appearing with matter-offact righteousness in the daily lives of men and women, regardless of their attendance record at Sunday mass. Under the auspices of a greater network of 
power mechanisms, the incitement to speak of sex and optimization of sexual discourse began to spill over, beyond the purview of Christian spirituality, and demand the production of sex discourses according to newer political, economic and biological incitements (Foucault 1978, 23).

Beginning in the eighteenth century, the need to talk about sex was no longer seen as solely a subject of spirituality and morals, but also, and more and more importantly, a matter of public reason (Foucault 1978, 24). Of note is the fact that this new incitement to discourse did not, according to Foucault, take the form of a general theory of sexuality, but rather "the form of analysis, stocktaking, classification, and specification, of quantitative or causal studies" (ibid. 23-24). Like the discursive economy belonging to the Christian pastoral, sex had to be "taken into account," in all its detail (ibid. 24). However, in the eighteenth century, inciting talk of all the gritty details of sex was no longer a simple matter of decipherment and judgment, but also took on the additional requirement of being something which one administered (ibid. 24).

Certainly, sex was given more occasions to be valued according to the new utilitarian ethic coming out of the Industrial Revolution. However, as the case of the Christian pastoral clearly indicates, the optimization of sexual discourse first took form in the seventeenth century, at least a century prior to it becoming what Foucault calls a "police matter," in the eighteenth century (ibid. 24-25). Here, in the eighteenth century, sexual discourse became a fully-fledged matter of the policing of sex, in the full sense of the term; that is, not simply a matter of repressing disorder but, more importantly, of maximizing the order of "collective 
and individual forces" (ibid.). Most importantly, then, a transformation occurred at the level of power's domain of application, where sex and sexual discourse began to function, not so much as a matter of taboo, censorship and denial, but rather of regulation, administration and public use (ibid. 25).

Foucault provides a general example of this technological change in power taking place at the level of its domain of application by discussing the notion of a "population" that grew out of the eighteenth century as a particular economic and political problem $(1978,25)$. Governments began perceiving their actions as being exercised, no longer simply on individual subjects, or even a "people," says Foucault, but rather as being exercised on a collection of individuals viewed as an organism unto itself (ibid.). This notion of a population was a matter of wealth, labour capacity and the overall balance between growth and available resources (ibid.). Grouping together the everyday lives of all men, women and children, populations represented problems of "birth and death rates, life expectancy, fertility, state of health, frequency of illnesses [and] patterns of diet and habitation" (ibid.). And it was sex, says Foucault, which grouped together these diverse economic and political problems. It became necessary to understand and monitor birth rates, the ages of newly married couples, the number of legitimate and illegitimate births, and the precocity and frequency of sexual relations, as well as their level of fertility or sterility (ibid. 25-26). Says Foucault, it was the first time in which the future and fortune of a developing society had been directly associated with "the manner in which each individual made use of his sex" (ibid. 26). 
As a consequence of this new notion of a population, what Foucault calls the "ritual lamenting over the unfruitful debauchery of the rich, [of] bachelors and libertines" was replaced by a very specific discourse concerning the sexual conduct of the population, taken as a novel object of analysis, but also a target of intervention $(1978,26)$. The salient feature of this new political economy of population was its grid of observations and interventions regarding sex, composed of power mechanisms that took on a new technological component in the capacity, as well as the requirement, to intervene, regulate and administrate sex. Power was not only applied within the domain of its own discursive economy, but activated a novel set of technological functions therein; and the sexual activities and identities of libertines were no longer seen simply as debaucherous, but were also scorned for their lack of productive contributions to the population of the state. This change was made possible by new points of analysis for evaluating modes of sexual conduct and by a novel housing of the determinations and effects of sex within biological, economic and political areas of knowledge. However, from the point of view of power's domain of application, there occurred a transformation at the level of the very technological functions of power. There was a concerted effort to transform sex into malleable economic and political behaviours and sex became a public issue of grave importance; however, sex also became something that all individuals had to internally monitor as well as externally disclose (ibid.).

Since the eighteenth century, then, transformations taking place at the level of technologies of power optimizing the discursive economy of sex bore 
new mechanisms of power that did not simply impose silences upon sexuality. Rather, the transformation extended the possible forms according to which sex could be put into discourse, on the one hand, and multiplied the mechanisms according to which power could penetrate sex, on the other hand. New sites for the implantation of sex were established and power began to codify the contents of sex and qualify its speakers in new ways $(1978,29)$. The policing and administration of sex intensified along new institutional sites and according to emergent polymorphous techniques of power began to implant new sexual norms and regulations into a greater number of bodies.

Of note is the fact that Foucault describes the introduction of power's technological mechanisms into the body using the language of penetration and implantation. The narrative form according to which these textual allusions describe power's hold on the body situates the perspective from which Foucault himself speaks of power and its deployment in relation to bodies. Power is what deploys the apparatus of sexuality, incurring an incitement to discourse verbose and necessary - and resulting in a corresponding transformation of power's technological functions. Foucault describes power's resulting technological functions as embodying a particular sexual capacity that is alluded to with the term "penetration." It can be read that power penetrates sex with the same force and zeal of an intimate sexual encounter. Furthermore, it can also be read that power implants sex within the body with the particular force of a nonpenile/vaginal copulation-like act. 
As it shall continue to be shown, Foucault's Will to Knowledge describes a growing network of power relations that functions according to an apparatus of power and knowledge capable of producing sex itself with the body. At the level of the text's narrative form, however, Foucault will continue to describe the workings of the power apparatus called "sexuality" and the deployment of its technological mechanisms in terms akin to what could be called a perverse eroticism. 


\section{Chapter: Of Other Sexualities}

\subsection{The Multiplication of Polymorphous Powers}

Throughout the Middle Ages and up until the end of the Renaissance, there existed one generally-agreed upon discourse concerning sex, organized around the theme of the flesh and the practice of penance $(1978,33)$. But over the course of the last three centuries, this unified discourse was shattered into multiple discourses that found a new place within disciplines as diverse as economics, demography, political criticism, biology, medicine, psychiatry, psychology, pedagogy and ethics (ibid.). Foucault's History of Sexuality: The Will to Knowledge attempts to qualify this break by demonstrating how what Foucault calls "the secure bond that held together the moral theology of concupiscence and the obligation of confession" was diversified into a multiplicity of new, different and often incompatible discursive conceptualizations of sex (ibid.). Among these attempts at translating sex into the various languages of each discipline, Foucault notes that there existed at least one commonality in the domain of application of these new discursive conceptualizations: that power makes sex an object of discourse according to mechanisms that require individuals speak of sex and have it spoken about (ibid. 33-34).

Where we have become accustomed to associating the history of sexuality with a tale of sex's absolute repression and future liberation, Foucault provides a historical inquiry into what he terms the "polymorphous incitement to discourse" (ibid. 34). As another key literary device, the term "polymorphous" plays multiple roles in Foucault's text. At first, it indicates that between the 
seventeenth and nineteenth centuries historical events concerning sexuality were localized at multiple, as well as heterogeneous discursive sites. These ranged from economics and politics, to medicine and pedagogy. However, the term "polymorphous" also indicates that a historical transformation occurred at the level of power's domain of application, where new mechanisms of power began to modify the very bodies of individuals with respect to their sexual activities, interests and even identities. Finally, Foucault's use of the term 'polymorphous' also alludes to Freud's notion of 'polymorphous perversity', a psychoanalytic term used to describe the diffuse desires of infantile sexuality before they are suppressed by social conventions, which Foucault uses as an image to further explain the manner with which power modifies sex and the body.

The effects Foucault achieves with the nuances of the term 'polymorphous' allow him to describe the plurality of recent historical events surrounding sex from multiple points of view. Over the past three centuries, sexual discourse has had much less to do with repression than with proliferation, extension and multiplication; however, the proliferation of sexual discourses, says Foucault, has subsequently been a matter of the dispersion, diversification and complexification of the centres from which sexual discourses emanate (ibid.). A greater number of disciplines, institutions and individual relationships were made to speak of sex with greater external and internal necessity. In Foucault's words, sex's general incitement to discourse had been constituted by way of "polymorphous techniques of power" (ibid. 34). 
For example, by the eighteenth century, the incitement to discourse so fundamental to the history of sexuality saw not only a proliferation of discursive centres, but also a "diversification of their forms" according to a "complex deployment of the network connecting them" (ibid. 34). Medical, psychiatric, and criminological disciplines turned their attention to the sex of a greater number of individuals. A number of new devices and mechanisms were thus invented for speaking about sex, for having sex be spoken about and for inducing sex to speak of itself, followed by new technologies for listening and redistributing all of which was said (ibid.). Medicine began speaking of sex using the language of "nervous disorders" $(1978,30)$. Psychiatry set itself the task of discovering the original cause of mental illness in "sexual illnesses" (see ibid.). Criminal justice broadened its jurisdiction to include a greater number of sexual acts (ibid.). Around sex, an elaborate network of discursive knowledge and technologies of power emanated from these various institutional sites (ibid.). Like the Christian pastoral, with its confessional practices and codes regulating spiritual guidance, these newly formed centres for the incitement to discourse were built upon carefully articulated and highly hierarchized networks of power relations. In this way, says Foucault, a good number of social controls marked the eighteenth and nineteenth centuries with a thorough forensic investigation of every individual's sexuality (ibid.).

What was most noteworthy, then, about the incitement to discourse in the sixteenth and seventeenth centuries was the subsequent deployment through the eighteenth and nineteenth centuries of greater and more complex networks of 
power relations. Sexual discourses had been proliferated and multiplied to the point where there existed a greater number of disparate sexualities, which, in concordance with their respective discourses, were then further multiplied by means of a general strengthening of their different forms (ibid. 37). In the early nineteenth century, says Foucault, a vast array of sexual heterogeneities were born (ibid.).

For example, the multiplication of polymorphous techniques of power in the eighteenth and nineteenth centuries significantly modified the general system of alliance governing the monogamous family unit (ibid. 38). Heated debates over the laws of marriage began to cool and talk of conjugal monogamy was replaced by a growing attention and scrutiny paid to "peripheral sexualities": the sex of children, of mad men, women, criminals, "the sensuality of those who did not like the opposite sex" and the sex of those subject to "reveries, obsessions, petty manias, or great transports of rage" (ibid. 38-39). As a result, the law of marriage and the order of desire - what Foucault calls the two great systems conceived by the West for governing sex - were significantly transformed, as the close monitoring of the sexual habits of men and women was overturned by a zealous analysis and classification of manifold "perversions" (see 1978, 39-40).

Consequently, the "unnatural" was awarded its own specific dimension in the emergent field of sexuality $(1978,39)$. Previously condemned sexual activities such adultery or rape were internally divided along two fault lines: those activities which were seen as infractions against civil and moral codes pertaining to marriage and the family, as opposed to those activities which were seen as 
offences against the regularity of what had become the natural functions of sex (ibid.). The acts of practicing sodomy, engaging in sadism, or violating cadavers, for example, were perceived as both morally and criminally different from the acts, for example of marrying a close relative, of seducing a nun or of deceiving one's wife (ibid.). Perversion was given its own legal and moral order.

At this moment in time, Foucault suggests, the historical figure of Don Juan - "stealer of wives, seducer of virgins, the shame of families, and an insult to husbands and fathers" - was eventually eclipsed by a new personage: "the individual driven, in spite of himself, by the somber madness of sex" (ibid.). The prestige of the libertine was replaced by fear of the pervert, and an entire subrace was created that was very different from the libertines of the past (see 1978, 39-40). The world of perversions did not only call into question what Foucault calls "the natural laws of marriage" and "the immanent rules of sexuality" - it was altogether a slight upon these moral and legal orders $(1978,40)$.

By the end of the eighteenth century, those peripheral of sexualities populating the margins of society could be seen circulating through society's pores (ibid.). They were hounded, however, but not always by the law; they were very often locked up, but not always in prisons; and, yes, they were often sick, but their sickness was described as a scandalous and dangerous evil, the combined product of crime and vice (ibid.). Moreover, perversion wasn't simply the name for solitary travellers and "ramblers with bizarre impulses"; there was an entire family of perverts, made up of "children wise beyond their years, precocious little girls, ambiguous schoolboys, dubious servants and educators, 
[and] cruel or maniacal husbands" (ibid.). Their unnatural abnormality was successively classified as "moral folly," "genital neurosis," "aberration of the genetic instinct," "degenerescence," and "physical imbalance" (ibid.).

These various classifications, used among a heterogeneous set of disciplines, were said to represent advancements in the establishment of a science of sexuality; but what Foucault reads in their historical formation and development is a peculiar incitement to discourse, where polymorphous techniques of power function primarily by upholding moral and legal divisions, under the guise of medical terminology, at the same time as they penetrate sexual activities and individual modes of behaviour (see Foucault 1978, 53-54). The will to know sex was thus both the instrument and the object support for a great centralizing mechanism that brought together a heterogeneous set of powers, knowledge, and pleasures under the auspices of a single apparatus: that of sexuality.

\subsection{Productive Power}

The appearance of peripheral sexualities like those stamped with the mark of perversion, says Foucault, does not necessarily lead to the opinion that sexuality was beginning to express itself in greater amounts, despite the fact that it was regularly figured within a greater number of institutions, such as penal

colonies, tribunals, asylums and correctional facilities (see 1978, 40-41). But nor, necessarily, does it mean that sexuality continued to be thoroughly repressed by mechanisms of power and domination (see ibid.). Rather, by investigating the 
particular form which power takes when it is exercised in sexuality's discursive fields of application, it seems that various nineteenth century disciplines have, as Foucault says, made a forceful entry into the pleasures of individuals and their sexual relationships and began to manage them in the most intimate of ways (see ibid.)

It is according to a positive description of a productive set of power mechanisms that Foucault critically approaches the opinion that sexuality has been historically repressed. Furthermore, it is with the positive and productive character of power in mind that Foucault investigates the history of sexuality, not in terms of the formation of an idea or a mentality, but as a history of the form which power takes when it branches out and multiplies discourses and sets of knowledge surrounding sex; when it measures the body and penetrates individual modes of conduct, and when it takes hold of bodily pleasures and establishes within them a science of sex (see 1978, 48). In sum, at the level of its domain of application, this type of power produced a multiplication of discourses, a further production of sets of knowledge, an inducing of pleasures, and a generating of further power mechanisms (see 1978, 73). Thus, as a matter of the history of sexuality, power is deployed in a manner altogether different from the prohibitions and censorships of legal and juridical models of power (see 1978, 49).

The objective of Foucault's inquiry is to move away from a "theory" of power, towards what he calls an "analytics" of power $(1978,82)$. The aim is to develop an alternative account of power and of the way in which it is deployed in 
relation to sex. What he terms the "juridico-discursive" representation of power is what Foucault believes underlies the general theme that power essentially represses sex and the related idea that it is according to the functions of law that desire is originally constituted (ibid. 85). However, such a view of power assumes that power's relation to sex is essentially negative; that power enunciates sex solely in the form of the rule of law, that power controls sex according to prohibitions and threats of punishment, that power forbids sex by linking prohibition, censorship and denial in such a way the each is seen as both the instrument and the effect of the others, and that power is exercised over sex with homogeneous uniformity (see Foucault 1978, 83-85). Foucault argues that the general theme of power repressing sex and the particular idea of law constituting desire is the direct product of a representation of power based on a juridical model of power's effectiveness and, correspondingly, of a prohibitive view of its effect on discourse.

Indeed, since the middle ages, says Foucault, power has almost always been formulated according to the model of law, and since the French Revolution, we have become accustomed to viewing sovereign, monarchic power as unlawful $(1978,87)$. However, Foucault remarks that this strict judicial understanding of power betrays the historical fact that Western monarchies were themselves established by means of judicial powers and that their own power mechanisms were exercised according to legal and judiciary models of power (ibid.). In the eighteenth century, the French Revolution criticised monarchical power on behalf of a newer, more rigorous juridical system to which all political 
power could conform; but, notes Foucault, it never challenged the juridicomonarchic understanding of power itself (ibid. 88). In the nineteenth century, too, localized revolts and rebellions began to demonstrate that power could be exercised outside of the sphere of jurisprudence and that legal systems were but formalized manners of exerting violence; however, such criticisms still proceeded according to the assumption that power functioned according to the models of law and sovereignty. As Foucault sums up in the well-known eccentric phrasing: "In political thought and analysis, we still have not cut off the head of the king." (1978, 88-89). In other words, to get at the productive characteristics of power, we must imagine power without the king and sex without the law $(1978,91)$.

The method of Foucault's inquiry, then, distances itself from an analysis of power that presupposes the sovereignty of the state, that assumes its general form to be that of the law, and which grants the existences of number of uniform dominations at the outset $(1978,92)$. Rather, Foucault methodologically hypothesizes that power will not be sought in some unique source of sovereignty existing in a single, central point of application, but will rather be found in instances of multiple force relations (ibid. 93). Foucault's decentralizing methodology therefore stipulates that these instances of force relations will seek to ceaselessly transform, strengthen or reverse themselves through endless struggles and confrontations, that power in this case will sometimes support these relations but other times isolate them from one another, and that the strategies taking effect within force relations will be crystallized and embodied in institutional apparatuses and social hegemonies (ibid. 92-93). In sum, Foucault 
posits the omnipresence of power, as expressed in the oft-quoted phrasing:

"Power is everywhere; not because it embraces everything, but because it comes from everywhere." $(1978,93)$

Accordingly, power is hypothesized as being neither an institution, nor a structure, or even "a certain strength we are endowed with" - a view immediately at odds with the negative, "juridico-discursive" characterization of power and, for this reason, somewhat difficult to imagine at first $(1978,93)$. The description of power which Foucault has in mind is rather a grid according to which a given social order is made intelligible; it is a "moving substrate of force relations" that, by virtue of its inequalities and unbalances, is the very condition of possibility for relations themselves (ibid.).

Pursuing the method of this hypothesis further, Foucault suggests reversing Carl von Clausewitz famous dictum that "war is politics pursued by other means" $(1832,87)$. Rather, to grasp power's positive effects, it can be suggested that "politics is war pursued by other means," insofar as the force relations between individuals and states are but effects taking place in a permanently repetitious, inert and self-reproducing social order (see Foucault $1978,93)$. With this in mind, Foucault advances a number of propositions concerning power: namely, that power is something that is exercised rather than possessed; that it is immanent to economic, scientific and even sexual relations as both their conditions and their effects; that it comes from below rather than from on high; and, finally, that its relationality is intentional and calculated, but at the same time non-subjective, arising not out of individual choice but rather as an 
effect of the overall rationality of the comprehensive systems in which individual find themselves (see 1978, 94-95).

In this way, the power which Foucault describes as primarily productive is a power which, in the nineteenth century, did not exclude sexuality, but was rather its very condition of emergence, and which, consequently, penetrated behaviours by incorporating its polymorphous mechanism into bodies and into sex in the form of modes of specification for types of individuals (see 1978, 4748). As the grid according to which bodies and sex were made available for analysis, specification and subsequent qualification, the strategies of this productive power were embodied in an apparatus of power, knowledge and pleasure called "sexuality."

\subsection{The Perverse Implantation}

Foucault's full description of sexuality as an apparatus begins with the implantation of perversions within modes of behaviours and, ultimately, within bodies. Foucault demarcates four operations of productive power that, as altogether distinct from prohibition, are responsible for the implantation of sexual perversions into the bodies of the eighteenth and nineteenth centuries. First, "new lines of penetration" were drawn around the peripheral sexualities of the eighteenth century, and power mechanisms increasingly intervened and requalified the sex of children, women, mad men, and sexual deviants (see 1978, 41-42). As an example, Foucault contrasts the ancient prohibition of incest with the much more recent attention paid to the sexuality of children (ibid.). Neither 
attempt at regulating sex functions according to the same mechanisms, but not for the sole reason that the former is "a question of law and penalty" and the latter, a question of "medicine and regimentation" $(1978,41)$. Rather, notes Foucault, where the former prohibited consanguine marriages by seeking a simple decrease in the type of sex it condemned, the latter simultaneously propagated its own functional mechanisms and the many types of sex upon which these multiple mechanisms were brought to bear $(1978,41-42)$. The attempt to eradicate infantile masturbation, for example, proceeded by way of an indefinitely extended hunt mobilized around the sex of children (ibid. 42). Since the nineteenth century, the sexuality of children has been treated much less as a vice than as a polymorphous device supporting what Foucault calls an entire medico-sexual regime of power, knowledge, and pleasure. Not just children, but adults, too, as well as teachers, doctors and the state were entwined within its network, as a productive kind of power advanced and multiplied its relays and its effects, while at the same time expanding, subdividing and branching out its target into reality (ibid.).

Secondly, newly qualified classifications of perversion were incorporated into the sex and implanted into the bodies of these peripheral sexualities, resulting in a specification of new individual identities (see 1978, 42-44). For example, Foucault contrasts the ancient civil and canonical codes prohibiting sodomy with the delineation, in the nineteenth century, of the homosexual as a personage unto himself (ibid. 43). Where the sodomite was for so long viewed as nothing more than the juridical subject of the forbidden acts of sodomy, Foucault 
argues that the nineteenth century made the homosexual into a case history, a morphology, and a life form of its own, with a distinct past, a mysterious childhood, an indiscreet physiology $(1978,43)$. As Foucault says, the sexuality of the homosexual was "everywhere present in him": it was the root of all his actions, sexual or otherwise, because his perverse sexuality was his body's insidious first principle; his sexuality was immodestly written all over his body, because it was a secret his body constantly betrayed (ibid.). The psychological, psychiatric and medical category of homosexuality was first constituted in 1870 according to Foucault, when characterized by Carl Westphal's well-known article on "contrary sexual feeling" (1870) as less of a type of sexual relation than a quality of sexual sensibility, "a certain way of inverting the masculine and the feminine in oneself" $(1978,43)$. The ancient perversion of sodomy was recharacterized as a sort of interior androgyny - "a hermaphrodism of the soul" and the homosexual was given its own individual identity (ibid.).

Thirdly, what Foucault describes as "perpetual spirals of power and pleasure" were traced around bodies and sex was pursued not as a forbidden boundary, but rather according to a continual game of attraction and evasion (see 1978, 44-45). In a way altogether different from the taboos of old, Foucault explains, the form of productive power at work within the peripheral sexualities of the eighteenth century and the medico-sexual perversions of the nineteenth century resulted in an increased proximity between bodies and a constant interplay between sensations $(1978,44)$. Accordingly to Foucault, the medicalization of sexuality was both the instrument and the effect of this 
transformation (ibid.). Relying on a technology of health and pathology, sexuality became something to be detected in the depths of the organism, on the surface of the skin, or among the signs of behaviour, like a lesion, dysfunction, or symptom (ibid.). The result increased power's effectiveness and extended its domain of application; and at the same time incurred "a sensualisation of power and a gain of pleasure" (ibid.). The effect was twofold: an increased impetus in the exercise of power and an emotional reward for overseeing its extension (ibid.). The intensity of the confession rewarded the examiner's curiosity, says Foucault, and the resulting pleasure was fed back to the power being exercised (ibid. 44-45). In this way, power acted as a mechanism of attraction, drawing out the oddities over which it kept watch, while pleasure reinforced the power that harried it, as Foucault says.

In a fourth place, finally, new devices of sexual saturation began to characterize the space of the many social rituals surrounding sex, from those of the everyday lives of citizens and family members, to those of the furthest peripheries of sexuality and their perverted sexual activities (see 1978, 45-46). According to Foucault the institutions and social relationships of the nineteenth century were thoroughly saturated with sex. Where it is so often claimed that the legitimate sexual identities were reduced to the legitimate, conjugal couple at this time, Foucault holds that sex between men and women has, in fact, created, outfitted and been made to proliferate multiple types of sexual identity by way of circulating spirals of power and pleasure $(1978,45)$. According to Foucault, the sex of legitimate conjugal couples distributed not one but many centres for the 
interaction between power and pleasure (ibid. 45-46). From within these multiple centres, all sorts of different pleasures were pursued, compartmentalizing a whole set of "other" sexualities that were tolerated and sometimes even encouraged (ibid.). The family was but one of such centres (ibid. 46). Its established polarity between adult parents and children, for example, fuelled the attention focused on infantile sexuality, on the supposed dangers of masturbation, and on the importance attached to puberty (ibid.). However, educational and psychiatric institutions also constituted sites of distribution for the interplay between powers and pleasures; their hierarchies, spatial arrangements and surveillance systems supported proximities that functioned as mechanisms of intensification (ibid.). They too delineated places of extreme sexual saturation, where their privileged spaces, such as the classroom or the dormitory, as well as hierarchizing rituals, such as the visit or the consultation, activated bodily contacts that operated as inductors of polymorphous sexualities (ibid.).

Says Foucault, each one of these sites of sexual saturation constituted "a network of pleasures and powers linked together at multiple points and according to transformable relationships" (ibid.). The family unit, for example, was composed of many relationships and power relations that stood outside of the conjugal couple: the differentiations between children and adults, the established polarities separating the children's and parent's bedrooms, the regular segregation of girls from boys, the rules and norms associated with the nursing of infants, the importance attached to puberty, the dangerous necessity of household servants are but a few examples (ibid.). As a whole, these multiple 
relations constituted the plural forms of sexuality that were drawn and established from the centre of various sites of sexual saturation (ibid.).

In sum, throughout the history of sexuality, power has neither taken the form of law nor exhibited the effects of censorship (Foucault 1978, 47). Power did not close sexuality in on itself, but rather extended heterogeneous forms of sexual expression and pursued sex according to ever-deepening lines of penetration; power did not exclude sexuality or conceal the expression of sex, but rather attributed to sex the greatest form of reality by incorporating sexuality into the body as a mode of specification of individuals; power did not avoid sexuality, but rather produced a manifold number of sexual variations by means of mutually-reinforcing spirals of power and pleasure; finally, power did not set up a barrier against sexuality, but rather provided real spaces for the maximized saturation of sex (see Foucault 1978, 47). This productive kind of power "produced and determined the sexual mosaic" $(1978,47)$.

Therefore, concludes Foucault, modern society is indeed perverse - not in a metaphorical sense, because it has hypocritically repressed sex and its modes of expression in sexuality, which must be liberated if we are to hope for a better tomorrow (see 1978, 47). Rather, modern society is quite straightforwardly perverse, because it has deployed a manifold number of heterogeneous sexualities and has extracted from them, or rather, as Foucault says, has solidified in them - in people's bodies and their pleasures - a great variety of perversions according to a single apparatus called sexuality (ibid. 47-48). 
This implantation of perversions within bodies, says Foucault, is both the effect and the instrument of a consolidation, intensification and isolation of a whole set of sexualities to the peripheries of the sex of legitimate, conjugal couples $(1978,48)$. Children, women, mad men, and sexual deviants were relegated to places of extreme sexual saturation - the school house, the family household, the hospital, the mental asylum. In these places, the relations of power to sex and to pleasure were branched out and multiplied, and a novel technology of power began to measure the body and penetrate its individual modes of conduct (ibid.). The encroachment of this productive kind of power upon the body crystallized the panoply of these "other" sexualities according to different categories, such as age, place, and type of practice (ibid.). Says Foucault, the eighteenth century saw a "proliferation of sexualities through the extension of power" and an "optimization of the power" which transforms bodies into surfaces of localized interventions (ibid.). Since then, there has not only been an explosion of "unorthodox sexualities," but also - and most importantly - the deployment of a power apparatus that proliferates perverse pleasures and multiplies peripheral sexualities (ibid. 49).

\subsection{The Science of Sexuality}

From the incitement to discourse to the deployment of polymorphous technologies of power, the will to know sustaining the discursive economy of sex led to the establishment, in the nineteenth century, of a fully-fledged science of sexuality. However, in Foucault's view, it was a science of evasions because it's primary object of analysis was not the sex of legitimate, conjugal couples, but 
rather sexual "aberrations, perversions, exceptional oddities, pathological abatements and morbid aggravations" $(1978,53)$. It was therefore also a science that, while claiming to speak the truth, simply reiterated the moral view of the time concerning divisions between licit and illicit, normal and abnormal (ibid.). Against the backdrop of medical norms and biological urgency, the nineteenth century science of sexuality grounded its petty moralities in "truth" (ibid. 54). The basic lack of rigour of this "science," notes Foucault, is most evident when compared to discourses on the physiology of animal and plant reproduction at the time (ibid.). Their incongruities are striking. Sex seems to have been incorporated into two very distinct orders of knowledge in the nineteenth century: on the one hand, a biology of reproduction, developed according to what Foucault calls a general scientific normativity and, on the other hand, a medicine of sex, arising from different historical conditions of formation altogether (ibid.). Highlighting the difference between the two requires drawing out the will to know sustaining both attempts at constituting sex as a problem of truth (ibid. 56).

It is here that Foucault develops his notorious distinction between what he calls the scientia sexualis of Western civilization and the ars erotica of many Eastern civilizations (see 1978, 57-58). With very broad strokes, Foucault paints a stark contrast between two opposing procedures for extracting truth from sex, one based on an art of mastery over the body and its pleasures $(1978,57-58)$ and the other, based on an authentication of one's self by discourses of truth one was obliged to confess concerning one's self (/bid., 58-59). However, after the publication of The Will to Knowledge, Foucault would indicate that, in retrospect, 
he would have preferred to oppose the Western science of sexuality with a contrasting practice that nonetheless is still a part of Western culture (see Foucault $1984 \mathrm{a} / 1997,259)$. This should not be read as a retraction of the initial contrast between the science of sexuality and the erotic arts, but it does leave some room for additional description of the more provocative contentions of Foucault's account of the production of the truth of sex in the West.

As Foucault says, "the transformation of sex into discourse" and "the dissemination and reinforcement of heterogeneous sexuality" are two elements of a same deployment: "they are linked together with the help of the central element of a confession that compels individuals to articulate their sexual peculiarity" $(1978,61)$. "Western man has become a confessing animal," as he says (ibid. 59).

This is due to the deployment of a centralizing, confessional mechanism at the interface of two modes for the production of truth: procedures of confession and procedures of scientific discursivity (ibid. 65). Gradually, the extortion of sexual confessions became constituted in "scientific" terms. It began with a "clinical codification of the inducement to speak" - confession was fused into practices of medical examination and a set of decipherable signs and symptoms of sexual perversion was deployed within a field of scientifically acceptable observations (ibid.). Then, a "general and diffuse causality" was postulated at the heart of the medical confession - sex was endowed with "an inexhaustible and polymorphous causal power," so that even the most discreet of sexual behaviours was deemed capable of entailing the most consequences within 
one's own existence (ibid. 65-66). This, then, incurred a principle of latency intrinsic to sexuality - sex was deemed elusive by nature: hidden from the subject himself, and thus the labour of confession was a responsibility for both the questioner and the questioned (ibid. 66). Then, in turn, confession ascended to the level of scientific potency through its method of interpretation - the scientific validity of the truth of sex became a matter of both the revelation of confession and the scientific decipherment of what it said (ibid. 66-67). Finally, then, the scientificity of confession was crowned with a medicalization of its effects - confessions obtained and their effects deciphered were recodified into therapeutic operations: sex was "placed under the rule of the normal and the pathological," as its latent meaning and necessary revelation was ensured by medical interventions and the healing truths thereby provided (ibid. 67).

Says Foucault, it is this deployment of a complex machinery for producing true discourses on sex that enables sexuality - viewed as a power apparatus - to literally embody the truth of sex and its pleasures (ibid. 68). "Sexuality," in Foucault's view, is thus the correlative of an ancient injunction of confession that has been fused to modern clinical methods of observation and decipherment (Ibid.). And because of its historical formation at the intersection of techniques of confession and mechanisms of scientific discursivity, sexuality continues to define not only the very "nature" of sex, but also the very "truth" of ourselves. Overall, the science of sexuality initiated two processes for positing sex as a problem of truth, each one always conditioning the other (ibid. 69). On the one hand, there was the demand that sex speak the truth; on the other hand, there 
was the demand that sex tell us our truth (ibid. 69-70). However, since our truth was a truth about ourselves so deeply buried within us, it constantly escaped us and, similarly since sex was latently secretive, speaking the truth of sex's truth was a function reserved for the science of sexuality (ibid.).

Foucault demonstrates that the double conditioning of the science of sexuality was supported and sustained by a will to know sex that was as heterogeneous as it was polymorphous; first, because there was no single, allencompassing strategy involved in the various manifestations of sex over the past two decades; and second, because there was rather a manifold number of objectives aimed for, a plurality of means employed, and a whole list of age groups and social classes affected (see ibid. 103). Furthermore, from the incitement to discourse to the polymorphous deployment of its technologies of power and knowledge, this science of sexuality operated according to a paradoxical assemblage of different powers, pleasures, and knowledge. Foucault identifies four strategic unities formed specific mechanisms of knowledge and power centered on sex.

In a first place, according to Foucault, there emerged in the eighteenth century a threefold process whereby women's bodies were qualified (and disqualified) as places thoroughly saturated with sexuality (ibid. 104). Women's bodies were thoroughly analyzed according to their innate capacity for hysteria, were integrated into the medical sphere by reason of this intrinsic sexual pathology, and were placed at the peripheries of normal sex with regard to spaces such as the social body (whose fecundity she was nonetheless required 
to ensure), the family milieu (of which she was a substantial and functional element) and the lives of children (which she has to both produce and guarantee) (ibid.). In a second place, Foucault identifies the pedagogization of the sex of children according to a double assertion that all children are prone to inevitably indulging in sexual activity and that this sexual activity posed physical and moral, as well as individual and collective dangers (ibid. 104). Children were placed astride two sexualities, at once "natural" and "contrary to nature," as the "precious and perilous," "dangerous and endangered" sexual potentialities were neatly juxtaposed within their bodies (ibid.). In a third place, another threefold process emerged in the eighteenth century that led to a thorough socialization of procreative behaviour: an economic socialization brought to bear on the fertility of conjugal couples, a political socialization regarding procreative responsibilities faced by couples towards the community; and a medical socialization of the couple through pathogenic values attributed to birth-control practices with regard to the overall well-being of the social body (ibid. 104-05). The socialization of procreative behaviour thus brought about a paradoxical use of sex by the state incurring various incitements and restrictions (ibid.). In a fourth place, Foucault identifies the overall psychiatrization of perverse pleasure as a means of isolating the instinctual drive for pleasure as a unique biological and psychical instinct (ibid. 105). Says Foucault, a clinical analysis constituted all the forms of anomalies according to which pleasure could be affected, a role of normalization and pathologization was assigned to all forms of pleasurable behaviour, and a corrective technology was established for each anomalous pleasure (ibid.). 
Overall, then, sex was no more hidden from view that it was repressed by bourgeois society. Rather, as Foucault shows, it shone forth; it was incandescent (ibid. 77). Sex was placed at the centre of a will to know that established a science of sexuality for deciphering what could be said about the truth of sex and for obtaining that part of the truth of sex that constantly escapes us (ibid. 71). Ironically, the result was a new kind of pleasure: "pleasure in the truth of pleasure," as Foucault describes it: "the pleasure of knowing that truth, of discovering and exposing it, the fascination of seeing it and telling it, of captivating and capturing others by it, of confiding it in secret, of luring it out in the open - the specific pleasure of the true discourse on pleasure" (ibid.). 


\section{Chapter: The Ethics of the Foucauldian Body}

\subsection{The Will to Know Sex}

With a view to further describing the will to know sustaining the establishment of a science for producing the truth of sex, Foucault offers a description of the historical development of sexuality as it relates to apparatuses of alliances $(1978,106-07)$. All relations of sex, explains Foucault, give rise to an apparatus of alliance, containing systems of marriage, of kinship ties, of the transmissions of names and possessions, for example (ibid. 106). According to Foucault, the historical development of sexuality was in a very important way made possible by this apparatus of alliance (ibid.). In fact, it is Foucault's view that, from the eighteenth century, onward, Western society created and deployed a new apparatus that would slowly be superimposed upon the apparatus of alliance (ibid.).

This new apparatus was the entire machinery of sexuality, which, like the apparatus of alliance, would provide a field of connection for sexual partners but in a completely new way (ibid.). On the one hand, the apparatus of alliance has the objective of reproducing what Foucault calls the interplay of relations and of maintaining the law that governs them. On the other hand, the apparatus of sexuality results in "a continual extension of areas and forms of control" (ibid.). The former concerns itself with the link between relationships and legal statutes, the latter with "the sensations of the body, the quality of pleasures, and the nature of impressions, however tenuous or imperceptible these may be" (ibid.). Most importantly, Foucault hypothesizes that, if the apparatus of alliance is tied 
to social and political economies in lieu of transmissions and circulations of wealth, then the apparatus of sexuality is linked to these economies via the body and its capacity of production and consumption (ibid. 106-07). Says Foucault, where the apparatus of alliance has the function of maintaining the social body as a whole, the apparatus of sexuality has the function of "proliferating, innovating, annexing, creating and penetrating bodies in an increasingly detailed way" (ibid. 107).

Foucault attributes the following timeline to the historical construction of sexuality. First, the practice of penance and the examination of conscience through practices of confession and spiritual direction formed the early nucleus of the apparatus of sexuality. What was at issue, according to Foucault, was the investigation of sex as a basis of relations, distinguished according to what was allowed and what was forbidden $(1978,107)$. At the level of the body, sex was seen as a point of fixture according to which bodies could enter into relations with one another. Then, when the power of sexual investigation spilled beyond the realm of the new pastoral, sex became the matter of a different problematization and was not only applied at the site of the seminary, but also in secondary schools and convents (ibid. 107-08). According to Foucault, sex gradually progressed away from being a problem of relations to becoming a newer problem regarding the "flesh": that is, a problem of the body, of sensations, of the causality of pleasure, and of secret forms of acquiescence (ibid. 108). Once again, at the level of the body, sex was transformed from a point of fixture to a 
mobile target and its place within the body was widely expanded, beyond its capacity for sexual, towards a new capacity for illicit pleasure.

For Foucault, the apparatus of sexuality first takes shape within these two movements. In order to fully develop his argument that sexuality is not a natural kind of embodiment, but rather an apparatus of power and knowledge, Foucault relates his historization of sexuality to the apparatus of alliance. Sexuality, he says, was born of a technology of power that allowed it to operate in conjunction with a system of alliance that acted as its main ground of support: the family $(1978,108)$. The family cell, says Foucault, in its eighteenth century form, made it possible for the apparatus of sexuality to develop, not in isolation, but rather in an application of its techniques of power and knowledge according to four related strategies: those of "the feminine body, infantile precocity, the regulation of births, and to a lesser extent no doubt, the specification of the perverted" (ibid.). More concretely, however, such technologies of power encroached upon the bodies of women, children, and homosexuals by means of a new specialization of their bodies with regards to sex. The overall strategy for the encroachment of power was an implantation of perversions. Once again, the term "implantation" here refers to the perversions placed within the body as modes of individual specification; however, at the level of the text's narrative form, the implantation of perversions within the bodies of women, children, and homosexuals alludes to the "perverse" character of the power being deployed. The implantation of perversions within the body is a perverse implantation, in the sense that it results in unintended and contrary effects. Though deemed perverse, the bodies of 
women, children, and homosexuals were designated a "sexuality" of their own. The implantation of perversions therefore had the unintended effect of affording these "other sexualities" a number of pleasures that were also their own and could therefore disrupt the initial goal of sexuality's deployment of perversions within the body.

The perversity of perversions aside, Foucault notes that his formulation of sexuality as a power apparatus is not meant to describe the family cell as a structure of alliance that excludes sexuality $(1978,108)$. Rather, with a view towards further explaining the will to know that sustains the establishment of sexuality as the basis for knowing the truth of sex, Foucault demonstrates how familial alliances ensure the production of sexuality by acting as a point of interchange between sexuality and alliance (ibid.). As Foucault explains, where the apparatus of sexuality was born on the fringes of familial institutions (in religious and pedagogical settings, more specifically), it soon found an anchor and place of permanent support in the family (ibid. 110). This is because, within the familial institutions, parents and other family members became the first point of contact for the application of an apparatus of sexuality that was only secondarily supported from the outside, by doctors, educators, and later, by psychiatrists (ibid.). From the very moment of this new point of contact, new personages made their appearance:

"the nervous woman, the frigid wife, the indifferent mother - or worse, the mother beset by murderous obsessions - the impotent, sadistic, perverse husband, the hysterical or neurasthenic girl, the precocious and already exhausted child, and the young homosexual who rejects marriage or neglects his wife" $(1978,108)$. 
Taken as a whole, these were the figures of a corrupted alliance and an abnormal sexuality $(1978,110-11)$. More importantly, it is because of "unnatural" sex that sexuality was understood as a corrupted alliance, and because of the familial system of alliance that sex became a matter of its own system of alliance - an apparatus unto itself - able to assert the prerogatives of a new order of sexuality (ibid. 111). From this interaction between alliance and sexuality emanated a pressing new demand: to reconcile the unfortunate discrepancies between the family and other sexualities. The familial system of alliance spelled out a lengthy complaint of sexual suffering to all the "experts" who would listen: priests, pastors, educators, doctors, and psychiatrists (ibid.). Consequently, the family became the site for an indefinite search for the slightest inclinings of sexuality, extracting the most lengthy of confessions from itself and all others. In this way, Foucault calls the family the crystal in the deployment of the apparatus of sexuality, as it was the prime source of sexuality which it then reflected and diffracted.

All in all, the purpose of Foucault's study of the history of sexuality is to directly connect the deployment of productive power to the body: "to bodies, functions, physiological processes, sensations, and pleasures" (ibid. 152). The stated purpose is to demonstrate the extent to which biological and historical constitutions of the body are bound together according to a complex development of modern technologies of power (ibid.). Thus, the history of sexuality is a "history of bodies" that surveys the manner in which what is seemingly most material and most vital with respect to bodies has been invested 
in bodies (ibid.). Here, we can begin to situate the movement of Foucault's thought as it balances between descriptive and prescriptive ethical claims.

Consequently, along the historical lines of development of the apparatus of sexuality, Foucault outlines the production of sex itself, in the idea that there is something more hidden within the body than simple organs, functions, sensations, or pleasures (ibid. 152-53). For example, from within the process of the hysterization of women's bodies, "sex" was defined as that which belonged to both women and men, but also as that which belonged exclusively to men and was therefore lacking in women, and finally, as that which in itself constituted the female anatomy, ordered wholly in terms of reproductive functions that kept women's bodies in a state of constant agitation (ibid. 153). Women's bodies were thoroughly saturated with "sex" by means of the notion of hysteria, understood as the movement of this "sex" from essential principle to fundamental lack (ibid.). From within the pedagogization of the sex of children, too, there formed the idea of a "sex" that was present and absent in children's bodies: present in the capacity for sensual pleasure but lacking in the ends of reproduction (ibid.). From within the psychiatrization of perversions, "sex" was defined as an intricate correlation between biological functions and psychological instincts according to which the signs and symptoms of perverse behaviour could be made intelligible (ibid. 153-54). Finally, from within the socialization of procreative behaviour, "sex" was measured according to an economy of pleasure that was seen as constantly attempting to circumvent a law of public necessity (ibid. 154). 
In the four major forms of hysteria, onanism, fetishism, and interrupted coition, the apparatus of sexuality showed this "sex" to be governed by the interplay of whole and part, principle and lack, absence and presence, excess and deficiency, and by the functions of instinct, finality, and meaning, a constant movement away from pleasure, towards the "realities" of "sex" (ibid.).

\subsection{Utopian Body}

That sex has not been historically repressed so much as it has been discursively produced and multiplied according to a greater number of social relationships and institutions can be read as a straightforward claim. However, how is it that, from the sixteenth and seventeenth centuries, to the eighteenth and nineteenth centuries, sex was historically transformed from something that must be monitored, on account of it being the origin of sinful yearning and the desires of the flesh, to becoming something that must be surveyed, prescribed and administered along multiple sites and according to a diverse number of mechanisms? Foucault claims that it is according to newly emergent power mechanisms that the contents of sex become codified and its speakers qualified in new ways (see 1978, 29). Thus, the most difficult task of an attentive reading of Foucault's History of Sexuality: The Will to Knowledge involves grasping how exactly he argues that new technologies of power are implanted into social relationships, into the body, and into sex itself.

We may well grant Foucault the idea that, by the nineteenth century, a heterogeneous collection of sexualities appeared according to different ages 
(children, as well as adults), different tastes or practices (fetishisms, as well as homosexual preferences), different social relationships (between parents and children, as well as between doctors and patients), and different spaces (within the home, as well as at the doctor's office) $(1978,47-48)$. It is nonetheless difficult to understand why Foucault insists that these manifold sexualities are but the correlates of procedures of power, as he says (ibid. 47). For Foucault, the nineteenth century is an age of manifold sexualities, where the growth in the number of perversions is not the result of a thorough repression of sexuality, but rather what Foucault describes as an encroachment of a polymorphous and productive kind of power upon bodies and their pleasures $(1978,48)$. How then, does Foucault understand the body and how is it that the body is receptive to the encroachment of powers?

Some clarification is provided when Foucault describes the establishment of a science of sexuality, midway through this first volume of The History of Sexuality (see 1978, 53-73). However, with its particular attention paid to describing the will to know sex driving and sustaining the science of sexuality, this section does not directly address Foucault's understanding of embodiment and its relationship to the productive character of power. The direction Foucault takes is one that addresses the relationship between power, sex and truth. For example, Foucault famously claims that homosexuality was only made into a fully-fledged identity in the nineteenth century, when new mechanisms of productive power took aim at the body of the pervert and rather than suppressing it, gave it "an analytical, visible and permanent reality" (1978, 43-44). The claim 
that a homosexual category of identity was not possible prior to the interventions of productive power in the nineteenth century is at first rather shocking. However, that homosexuality was "made into a principle of classification and intelligibility" according to a specific historical process does fit Foucault's prior description of the productive character of the power and the historical implantation of perversions into the body. Nonetheless, a case could be made for requiring further description of the particular manner through which power implants sexual identities, such as that of the homosexual, into bodies themselves, and how sex can be "slipped in beneath modes of conduct," as Foucault says (ibid. 44).

Foucault describes the overall historical development of sexuality according to a will to know understood as the condition of possibility for the truth of sex. It is according to such a will to know that sexuality becomes established as the raison d'être of multiple and polymorphous power relations centered on sex, as well as the natural order of all the disorders existing within heterogeneous sexualities (see 1978, 43-44). However, if this is the case, then it is also according to a certain functionality, capacity or character of embodiment and subjectivity that power can implant the truth of sex within bodies.

Providing a fuller description of the productive kind of power at issue within Foucault's introductory volume to The History of Sexuality requires an interpretive device for explaining the strategy behind the dissemination of productive power mechanisms, given their capacity, as Foucault claims, to strew reality within the manifold sexual perversions and incorporate them into individual identities (see 1978, 43-44). One possibility for such a clarifying device can be 
found in a relatively under-cited text Foucault had prepared for a radio conference broadcast on the French radio channel, France-Culture, in 1966 (see Foucault 2009). Translated into English under the title "Utopian Body" (2006), the radio lecture can provide insight into what Foucault called his "analytic" of power by relating the form of his productive characterization of power in The Will to Knowledge to the form and operations according to which Foucault describes utopias and their relation to the body.

In "Utopian body" (2006), Foucault describes the notion of a utopia somewhat differently than its better-known meaning as the idyllic society described by Sir Thomas More (see More 1516). Rather than describing a utopia as a "good place," derived from the Greek words eu and topos, Foucault adopts a description of a utopia as "no place," from the Greek ou (Latinized as $u$ ) and topos. Sidestepping the values associated with More's utopia, such as the division between utopia and dystopia, Foucault states that a utopia is "a place outside all places" $(2006,229)$ and attempts to relate this description of utopias to the body as either the opposite of a utopia or a utopia onto itself. Interestingly, Foucault begins the radio lecture by borrowing from the description of the body figuring in the same opening passage of Proust's In Search of Lost Time (1922/2005) that he references ten years later in the opening passage of The Will to Knowledge (1978). Using the same description of the body as a literal place occupied anew every time the narrator awakes, Foucault once again achieves the same literary and philosophical effect: The unity of the speaking subject is put 
into question by dissociating the "I" from the "it," the "me, myself" from "my body" (Foucault 2006, 234n2).

At first Foucault hypothesises that utopias most often come into existence in an act of protest against the solid and unchanging character of the body (2006, 229). However, after some explanation of his initial hypothesis, he reverses his claim and hypothesizes that bodies are utopias unto themselves because they are the principal actor in all utopias, their materiality being but an effect of its own phantasms (ibid. 232). What stands out from Foucault's various claims concerning utopias and the body is a link that can be made between the historical construction of the body and the obstinacy according to which it asserts its presence; between its reducibility to categories of identity and its irreducibility to mechanisms of power figuring within it (see Potte-Bonneville 2012, 23).

Foucault begins the "Utopian Body" radio lecture with the hypothesis that the body that Proust occupies upon awakening is a place from which, "as soon as my eyes are open, I can no longer escape" $(2006,229)$. One can move from place to place, occupy a different place at different times - "I can hide in the morning under the covers" and "make myself as small as possible" - but this place "where I am," Foucault explains, "will always be there" (ibid.). A utopia is therefore not only "a place outside of all places," but also a place where one "will have a body without a body" (ibid.). Accordingly, utopias come into existence in an attempt to erase bodies. The body, says Foucault, is the most pitiless of 
places ${ }^{4}$ to which we are all condemned (ibid.). Thus, the body is the opposite of a utopia: it is "that which is never under different skies" (ibid.).

The cemetery, for example, can be viewed as a modern utopia whose very purpose is to erase bodies $(2006,230)$. As Foucault describes it, the cemetery is a place populated by bodies turned to stone; geometricized bodies turned into ornate slabs of marble (ibid.). In this "utopian city of the dead," he explains, the body becomes "solid like a thing, eternal like a God" (ibid.). Populated by bodies that are more solid than living bodies themselves, the cemetery is a place standing outside any real sense of space because it erases what Foucault calls "the sad topology of the body" (ibid.). As if against the body that pitiless of places - the cemetery replaces the obstinate emplacement of the body with another body, one that escapes that place to which, in our living bodies, we believe we are condemned.

More obstinate a utopia than the cemetery though is "that most powerful of those utopias with which we erase the sad topology of the body": the soul (ibid.). What Foucault calls "the great myth of the soul" supplied to us by Western history is a body "made smooth, neutered, rounded like a soap bubble" (ibid.). Though this utopia lives within the body, we imagine that it is always greater than the body because, though placed in the body, it occupies a space that transcends all the sad qualities of embodiment - obstinate emplacement, edges, angles, and physical form.

\footnotetext{
4 "Mon corps, topie impitoyable." (Foucault 2009, 3)
} 
However, continues Foucault, the body is not so easily erased and the hypothesis that utopias come into existence in an attempt to erase bodies must be abandoned (ibid.). As Foucault proceeds in his lecture, he begins to describe bodies as utopias onto themselves, even more profound than the soul or the tomb (ibid.). This is because the body, as he says, can be absolutely visible in one sense but at the same time also "captured by a kind of invisibility" in another sense (ibid. 231). "I know very well what it is to be looked over by someone else from head to toe," he explains; "I know what it is to be naked" (ibid.). But, on the other hand, one can never catch a glimpse of the back of one's skull with one's own eyes (ibid.). In this sense, then, the body can be like a phantom that can only be captured in the ruse of the mirror. Nothing better defines the philosophical notion of a "thing" than a body, says Foucault, in the sense that it is both visible and invisible (ibid.). On the one hand, it runs, acts, lives, and desires by letting itself be traversed by these movements with no resistance, becoming pure light - "transparent" and "imponderable" (ibid.). On the other hand, it hurts, hungers, crazes, and dies, becoming pure thing - a "fantastic," "ruminated architecture" (ibid.).

Proceeding with his analysis, Foucault reorients his previous claims by stating that all utopias are made possible by the most original and obstinate of utopias: the body (ibid.). The human body, says Foucault, is the "principal actor in all utopias" (ibid.). For example, it is the principal utopian actor when it comes to masks, makeup, and tattoos (ibid.). Wearing a mask, putting on makeup, or tattooing oneself, does not lead one to acquire a new body, suggests Foucault, 
so much as places the body in communication with "secret powers and invisible forces" - they inscribe upon the body enigmatic languages that summon the infinite powers of the religious and the profane (ibid.). These rituals tear the body away from its proper space and project it onto another space, allowing all the possible utopias sealed within the body to "blossom into sensible and colourful form" (ibid. 231-232).

For Foucault, this suggests that embodiment is somewhat like "the product of its own phantasm" (ibid. 232). That is, embodiment is less the product of the body's brute corporality than it is a consequence of its ability to radically transform itself anew according to an infinite amount of possibilities. Foucault therefore corrects his previous remark that the body was a pitiless place to which we are condemned and that it was in this sense opposed to utopias (ibid. 232-33; see ibid. 229). Rather, Foucault claims that the body as a utopia is that which "is always elsewhere" (ibid. 233). The body is "tied to all the elsewhere of the world" because, similar to the manner in which Proust describes the body, it is around the body that all things are ordered (ibid.; see Proust 1922/2005, 5-6). "My body," says Foucault, "is like the City of the Sun," alluding to the perfect theocratic society that the seventeenth century Dominican philosopher, Tomasso Campanella, envisioned as the catalyst and instrument of God's Divine Plan (Campanella 1623/2009), Like an absolute utopia, imagines Foucault, the body has no real place, "but it is from it that all possible places, real or utopian, emerge and radiate." 
With a final hypothesis, Foucault attempts to ground his musings on the utopian character of the body in a more practical understanding of embodiment. In a first place, he says, it takes a while for children to apprehend that they have a body and their "dispersed body of limbs [and] orifices" only becomes embodied in the image of a mirror $(2006,233)$. Foucault is here referring to the mirror phase of Jacques Lacan's psychoanalytic theory of infant self-recognition (see ibid. 234n4; see Lacan 2007, 75-80). Secondly, Foucault notes that the Ancient Greeks of Homer's writings altogether lacked a word for designating the unity of the body $(2006,233)$. According to Foucault, the only word for "body" that appears in Homeric literature is a word used to designate the corpse. From the Ancient Greek perspective, there were therefore no bodies guarding the walls of Troy, only "raised arms," "brave chests," "nimble legs," and "helmets shimmering atop heads" (ibid.).

Foucault therefore concludes that it is objects like the mirror and the corpse that teach us that the body occupies a space; that is has a form, an outline, a thickness and a weight (ibid.). "It is thanks to the mirror and the corpse," he says, "that our body is not pure and simple utopia" (ibid.). However, because the mirror and the corpse reside in inaccessible spaces - for we shall never reach the other side of the mirror and will never lay where our corpse will be laid to rest - Foucault concludes that it is only by means of utopian spaces that we can apprehend the "profound and sovereign utopia of our body" (ibid.). This is because utopias like the mirror and the corpse function by closing in on 
themselves in an attempt to mask the profound transformative possibilities of one's body.

In the end, making love, says Foucault, fulfills both functions of utopias regarding the body. "It is finally to exist outside of any utopia, with all of one's density, between the hands of the other" (ibid.). With fingers running against one's back, the invisibility of the body is electrified into sensory reality (ibid.). On the other hand, like the mirror and the corpse, the act of making love appeases the utopia of the body; it closes the body up onto itself and seals it shut (ibid.). To make love, then, is to be embodied in the fullness described here by Foucault because, as he says, "in love, the body is here" (ibid.).

\subsection{Bodies and Their Pleasures}

With attention paid to the narrative form according to which Foucault describes the utopian character of the body, it can be demonstrated that the body is composed of multiple registers according to which power may interact with it. It is important to note, however, that such registers compose the body only insofar as they describe the capacity of the body to interact with power. For in both "Utopian Body" and The Will to Knowledge, Foucault posits a brute corporality in the body only to replace it with a capacity for self-transformation immediately thereafter.

First, Foucault concludes in "Utopian Body" that embodiment is a matter of two utopian functions of the body. On the one hand, the body is defined according to its ability to close in on itself and seal the utopias of the body within 
itself. On the other hand, the body is defined according to its ability to exist outside of itself, in the arms of another, thereby existing outside of all the utopias contained within the body. To make love, says Foucault, is to feel the body here. This sense of presence is as much a sense of being myself, in my body, as it is a sense of being within another body, being that body at the same time as I am my own.

Similarly, in The Will to Knowledge, sex is defined as a matter of pleasure; it is a simple matter of bodies, contacts, sensations, organs, and physiological functions $(1978,152-53)$. However, the notion of sexuality has made sex into something more; something hidden and something meaningful. In this sense, sexuality is something altogether different from the pleasures of the body: it is both the anchorage point and the vessel for power relations in the application within the body (see ibid. 151-52).

As the very source of desire, "sex" constitutes itself as "an omnipresent meaning" and a "secret to be discovered everywhere": it functions as a unique signifier and a universal signified (ibid. 154). In the body, this notion of "sex" unifies a diverse number of heterogeneous elements, from biological functions to moral norms of behaviour. It marks itself as the necessary conduit between knowledge of human sexuality and the biological sciences of reproduction, allowing for certain contents of biology and physiology to serve as principles for distinguishing normality from abnormality within sexualized bodies (ibid. 155). It is thus through sex that each individual has to pass in order to have access to their own intelligibility, to the whole of their body, to their identity (ibid. 155-56). 
Foucault's Will to Knowledge therefore centres on an ethics of the body that describes the way we value our bodies through sex. By means of the apparatus of sexuality, "sex" becomes the pitiless place to which our bodies are condemned, for better or for worse. However, at the level of The Will to Knowledge's narrative form, a more prescriptive component to this ethics of the body actively performs the manner according to which "sexuality" and the Modern relationship between power, sex, and the body can be reoriented. Foucault demonstrates how, by means of the transformable power relationships figuring within the apparatus of sexuality, we may use the effects of power to give a different meaning to our bodies through pleasure. In opposition to "sex" as a signifier of meaning and a signified secret, pleasure fulfills what Foucault demarcates as the utopian functions of the body: pleasure grounds the body both within itself and within the both of an other. The result is an ethics of the body that at once describes the power relationships composing the apparatus of sexuality, as well as prescribes a reorientation of these relationships from within the very network of powers and sets of knowledge composing the apparatus of sexuality. Such an ethics of the body is descriptive in the sense that it portrays power's encroachment upon the body according to an apparatus of power and knowledge. However, this ethics of the body is also prescriptive, in the sense that it displaces the current relationship between power and sex away from secret truths and hidden meanings, in favour of the simple pleasures of embodiment.

When Foucault concludes in The Will to Knowledge that we must not refer the history of sexuality to an "agency of sex" but rather show how "sex" is 
historically subordinate to sexuality, Foucault actively demonstrates that "sex" is an imaginary point within the body determined by the apparatus of sexuality (ibid. 157). To historicize sexuality, then, is to demarcate this fictitious point within the body as it is situated by the deployed apparatus of sexuality and is invested by technologies of power (see ibid. 156). If sexuality is a historical constitution of the body, it is not to say that sexuality is an illusion masking the brute corporality of a biological sex intrinsic to the body; rather, it is to say that sexuality, as an apparatus of power and knowledge, is what gives rise to "sex" as more than a biological fact, that is, as what Foucault calls a "speculative element" necessary to the deployment of the apparatus of sexuality.

However, reading The Will to Knowledge's narrative form further indicates the manner according to which the power mechanisms of the apparatus of sexuality may be counter-deployed against the urgency to speak of sexuality as a matter of the truth and meaning of one's body. In Foucault's words, this urgency to speak of sexuality is the instrument-effect of a particularly Modern relationship established between sex and power. Accordingly Foucault's text actively demonstrates how we may break away from the corresponding view that by saying 'yes' to sex, we are saying 'no' to power (ibid. 157). When "sexuality" is in this way posited as somehow existing outside of power, the complex set of relationships assumed under the notion of "sex" attach themselves to an irreducible urgency to seek out the hidden secrets of sexual desire over and above any other relationship bodies and their pleasures may share with power (ibid.). The ethics of the body as described by Foucault's Will to Knowledge, 
then, actively resist the view that, by way of sexuality, we arrive at the essential agency of sex (see ibid.). At the level of the text's descriptive claims, such an agency of sex becomes but a fictional point in an application of power upon the body. At the level of the text's prescriptive claims, the mechanisms of this sexuality underlying this agency of sex are countered and resisted in favour of an alternative relationship between power and sex.

As Potte-Bonneville has noted, Foucault highlights the disparity that exists between categories of identity and their historical constitution through power relations exercised from within the body $(2012,37)$. The disparity relates to the fact that, for Foucault, the individuality of the body cannot be considered anterior or exterior to historical and political interventions; but nor, however, can it be exerted without conflict or resistance (ibid.). In as much as we may seek to transform categories of sexual identity, we must therefore mind the fact that these categories are themselves conditional upon productions of the body that are thoroughly marked by points of resistance (ibid.).

Here, then, is the central claim of the ethics of the Foucauldian body as it figures within The Will to Knowledge: Resist and counter the current relationship between power and sex "with the claims of bodies, pleasures, and knowledges, in their multiplicity and their possibility of resistance" (ibid. 157). We mustn't make the mistake, says Foucault, of thinking that "sex" is an autonomous material of the body that produces manifold effects expressed in sexuality in opposition to the grips of power (ibid. 156). Rather, as Foucault points out, "sex is the most speculative, most ideal, and most internal element in a deployment of sexuality 
organized by power in its grip on bodies" (ibid.). It is for this reason that Foucault states in the most oft-quoted phrase of The Will to Knowledge, that the "rallying point for the counterattack against the deployment of sexuality ought not to be sex-desire, but bodies and pleasures" (ibid. 157). Bodies and their pleasures constitute a point of resistance within the body because they tend to multiply the transformable relationship which their interactions with power produced, rather than extend the instruments and effects of desires as is the case with "sex." Like the incorporation of perversions within bodies in the nineteenth century, power applies itself to pleasure in order to anonymously control a vast array of sexual behaviours, but the consequence of this interaction between power and pleasure is the production of polymorphous and heterogeneous sexualities (see ibid. 46). Therefore, like the utopian functions fulfilled within the body when two bodies make love, the relationship between power and pleasure is one that always exceeds the relation of power to sex and to desire, resulting in unforeseeable consequences insofar as bodies are produced and pleasures are incurred.

When it is recognized that bodies and pleasures figure wholly within power, it is understood that they offer the possibility of reversing the grips of power upon the body by breaking the body away from a view of "sex" as a necessarily reflexive form of desire. Consequently, other pleasures may possibly figure within the body in relation to power. Such pleasures would include those which may bring about new relationships endowed with an even stronger capacity to once again reverse and transform the grip power has upon the body. As a matter of the ethics of the Foucauldian body, resisting categories of sexual 
identity multiplies the possibilities for future relationships between power, sex, and the body.

We therefore ought not to seek pleasure in opposition to power, but rather use power to critique the limits placed upon bodies in a demonstration that such limits are but the effects of historically constructed categories of identity. In as much as identities are understood to take place within power, we ought therefore to seek their transformation in an effort to alter the present hold power has on the body. Where the unity of the body is posited as a site of application for the mechanisms of productive power, we ought at the same time to uphold the heterogeneity of the body as a site for the polymorphous activation of pleasures and resistances. Foucault's inquiry into the deployment of power in relation to the body demonstrates that power's productive character is only possible given the heterogeneity of the body: the difference and diversity inherent to bodies (see Potte-Bonneville 2012, 41). Productive power emerges from the heterogeneous (ibid.). On the other hand, bodies are receptive to the grips of various powers because their heterogeneity activates power's polymorphous mechanisms and feeds back upon the body's heterogeneous form. Bodies activate the polymorphisms of power. Thus, Foucault's "bodies and pleasures" claim balances the descriptive and prescriptive ethics of Foucault's inquiry into the history of sexuality. The claim describes the historical formation of sexuality according to a descriptive ethics of the political constitution of the body, while at the same time calling for a transformation of the present hold power has on the 
body from within a prescriptive ethics of the polymorphism of power and the heterogeneity of the body. 


\section{Conclusion}

In conclusion, where sex is said to be repressed and is hoped to one day be liberated, Foucault demonstrates that the opposite is what is in fact at issue. Never have there existed more centres of power, he says, and never have there existed more sites "where the intensity of pleasures and the persistency of power catch hold, only to spread elsewhere" $(1978,49)$. Sex has been made to interact with power so as to deploy an entire political technology of the body by way of an apparatus of power and knowledge called "sexuality." However, the mechanisms of this apparatus can be countered from within its very deployment, relying on the two-way movement of the ethics of the Foucauldian body that both describes and prescribes those resistances made possible by the heterogeneity of the body and the polymorphism of power.

In a first place, there figures in Foucault's work an ethics of reading the bodies that he speaks of in his texts, such as The Will to Knowledge, as a reminder of that which exceeds every true characterization of the body (see Potte-Bonneville 2012, 41). In a second place, there also figures in Foucault's work an ethics of resistance against the grips of power taking hold of the body that reverses the very mechanisms of power at issue. In The Will to Knowledge, a reversal of the mechanisms belonging to the apparatus of sexuality is made possible by that which disturbs the grip of those powers deployed within the body. What exceeds the classifications and categories of sexual identity is the heterogeneity of bodies, in the sense of their difference and their diversity (see Potte-Bonneville 2012, 41). What disturb deployments of power and their grip 
upon bodies are power's own polymorphous techniques. It is therefore in this sense that Foucault's Will to Knowledge culminates in an ethics of the body that promotes the polymorphism of power and the heterogeneity of the body. 


\section{Bibliography}

Beer, Dan. 2001. Michel Foucault: Form and Power. Oxford: University of Oxford Press.

Bert, Jean-François. 2007. Michel Foucault: Regards sur le corps. Strasbourg: Édition du Portique.

Butler, Judith. 1989. "Foucault and the Paradox of Bodily Inscriptions." The Journal of Philosophy 86, no. 11 (November): 601-607.

Campanella, Tommaso. 1623/1980. The City of the Sun, translated by Luigi Firpo. Berkley: University of California Press.

Crome, Keith and Patrick O'Connor, eds. 2012. Foucault: Power, Politics, and Pleasure. Special issue, Journal of the British Society for Phenomenology 43, no. 1.

Dean, Tim. 2012. "The Biopolitics of Pleasure." The South Atlantic Quarterly 111, no. 3 (Summer): 477-496.

Dean, Carolyn J. 2012. "Afterword: The Agency of Sex: Volition after Foucault." The South Atlantic Quarterly 111, no. 3 (Summer): 549-562.

Dreyfus, Hubert and Paul Rabinow. 1983. Michel Foucault: Beyond Structuralism and Hermeneutics. Chicago: University of Chicago Press.

Dudrick, David. 2005. "Foucault, Butler, and the Body." European Journal of Philosophy 13, no. 2 (August): 226-246.

Eribon, Didier. 2001. "Michel Foucault's Histories of Sexuality." GLQ: A Journal of Lesbian and Gay Studies 7, no. 1 (31-86).

Foucault, Michel. 2009. Le corps utopique, suivit de Les hétérotopies. Clamecy: Nouvelles éditions lignes.

- 2006. "Utopian Body." In Sensorium: Embodied Experience, Technology, and Contemporary Art, edited by Caroline A. Jones, translated by Lucia Allais with $C$. Jones and A. Davidson, 229-234. Cambridge: MIT Press.

- 2004. Utopies et hétérotopies. Two radio conferences aired on FranceCulture, December 7, 21, 1966. INA-Mémoires vives. Paris: Institut National d'Audiovisuel. 
1998. The History of Sexuality, Volume 1: The Will to Knowledge. Translated by Robert Hurley. London: Penguin Books.

. 1986. The History of Sexuality, Volume 3: The Care of the Self.

Translated by Robert Hurley. London: Penguin Books, 1990.

. 1985. The History of Sexuality, Volume 2: The Use of Pleasure.

Translated by Robert Hurley. London: Penguin Books, 1998.

- 1984a/1997. "The Ethics of the Concern of the Self as Practice of Freedom." In Essential Works of Foucault 1, Ethics: Subjectivity and Truth, translated by P. Aranov and D. McGrawth, edited by Paul Rabinow, 281301. New York: The New Press.

—. 1984b. Histoire de la sexualité 2: L'usage des plaisirs. Paris: Gallimard.

. 1984c. Histoire de la sexualité 3: Le souci de soi. Paris: Gallimard.

1983/1997. "On the Genealogy of Ethics: An Overview of Work in Progress." In Essential Works of Foucault 1, Ethics: Subjectivity and Truth, translated by P. Aranov and D. McGrawth, edited by Paul Rabinow, 253280. New York: The New Press.

1982a/1996. "History and Homosexuality." In Foucault Live (Interviews, 1966-1984), translated by John Johnston, edited by Sylvère Lotringer, 293308. New York: Semiotext(e).

1982b/1997. "Technologies of the Self." In Essential Works of Foucault 1, Ethics: Subjectivity and Truth, english original, edited by Paul Rabinow, 223-251. New York: The New Press.

1980. Power/Knowledge: Selected Interviews and Other Writings. 19721977. Edited by Colin Gordon. Translated by C. Gordon, L. Marshall, J. Mepham and K. Soper. New York, Pantheon Books.

- 1978. The History of Sexuality, Volume 1: An Introduction. Translated by Robert Hurley. New York: Vintage Books.

- 1977. Discipline and Punish: The Birth of the Prison. Translated by Alan Sheridan. New York: Vintage Books.

— 1976. Histoire de la sexualité 1: La volonté de savoir. Paris: Gallimard.

Fox-Davies, Arthur Charles. 1909/2007. A Complete Guide to Heraldry. New York: Skyhorse Publishing. 
Freud, Sigmund. 1917. The Complete Introductory Lectures on Psychoanalysis, translated and edited by James Strachey. New York: W. W. Norton, 1966.

Huffer, Lynne. "Foucault's Ethical Ars Erotica." SubStance 38, no. 3: 125-147.

Jordan, Mark D. 2012. "Foucault's Ironies and the Important Earnestness of Theory." Foucault Studies 14 (September): 7-19.

Khalip, Jacques, ed. 2012. Future Foucault: Afterlives of Bodies and Pleasures. Special Issue, The South Atlantic Quarterly 111, no. 3.

Lacan, Jacques. 2007. Écrits: The First Complete Edition in English, translated by Bruce Fink. New York: W. W. Norton \& Company.

Lawler, Leonard and John Nale, eds. 2011. The Foucault Lexicon. Cambridge: Cambridge University Press.

Leclercq, Stéphan, ed. 2004. Abécédaire de Michel Foucault. Mons; Paris: Sils Maria; J. Vrin.

Lontringer, Sylvère. 2006. À satiété, traduit par Gérard-Georges Lemaire, édition revue et augmentée par l'auteur. Monaco: Désordres-Laurence Viallet.

- 1988. Overexposed: Perverting Perversions. New York: Pantheon Books.

Marcus, Steven. 1966. Other Victorians: A Study of Sexuality and Pornography in Mid-Nineteenth-Century England. Piscataway, NJ: Transcation Publishers, 2008.

McWhorter, Ladelle. 1999. Bodies and Pleasures: Foucault and the Politics of Normalization. Bloomington: Indiana University Press.

Miller, James. 1993. The Passion of Michel Foucault. New York; Toronto: Simon \& Schuster.

More, Thomas. 1519. Utopia, translated by Dominic Baker-Smith. London: Penguin Books, 2012.

Potte-Bonneville, Mathieu. 2012. "Michel Foucault's Bodies." Journal of the British Society for Phenomenology 43, no. 1 (January): 22-44.

Proust, Marcel. 1922/2005. In Search of Lost Time, Volume 1: Swann's Way, translated by C.K. Scott Moncreiff. London: Vintage. 
Punday, Daniel. 2000. "Foucault's Body Tropes." New Literary History 31, 3: 509528.

Reich, Wilhelm. 1936/1969. The Sexual Revolution. New York: Farrar,.

Revel, Judith. 2008. Dictionnaire Foucault. Paris: Éllipses.

Rocha, Leon Antonio. 2011. "Scientia Sexualis versus Ars Erotica: Foucault, van Gulik, Needham." Studies in History and Philosophical, Biological, and Biomedical Sciences 42: 328-343.

Waite, Gary. 2000. Reformers on State: Popular Drama and Religious Propaganda in the Low Countries of Charles V, 1515-1556. Toronto: University of Toronto Press.

Westphal, Carl. 1870. "Die Conträre Sexualempfindung: Symptom eines neuropathischen (psychopathischen) Zustandes." Archiv für Psychiatrie und Nervenkrankeiten 2: 73-108. 